\title{
THE SWEEPING-CLAIMS EXCEPTION AND THE FEDERAL RULES OF EVIDENCE
}

\author{
FREDERICK C. Moss*
}

Every trial lawyer and judge is familiar with the hoary rule of evidence that prohibits a hitigant from using extrinsic evidence to impeach a witness on a collateral matter. Despite the obvious difficulties in defining the terms "collateral," "extrinsic," and "impeach," the rule has long been recognized as valuable in regulating the scope of impeachment. This article examines the meaning and scope of the collateralmatter rule and the development of an exception to the rule. This exception, which recently has gamed acceptance im most courts, permits the imtroduction of extrinsic evidence to rebut sweeping claims or denials that a witness makes on direct examination, even though the testimony to be contradicted relates to a collateral matter. The article examines the "sweeping-claims" exception under the common law and under the Federal Rules of Evidence. ${ }^{1}$ It demonstrates that the federal courts have had difficulty accommodating the sweeping-claim exception within the framework of the new federal evidence code. Their problems reflect not only the code's failure to offer any guidance in this area, but also the sweeping-claims exception's lack of a solid underpinning im the common law of evidence. The article proposes that the sweeping-claims exception be elevated to an express rule because it is in accord with the general purposes of the modern evidence code, and because inost courts now endorse the exception. Its codification, through amendments to rules 607 and 608 of the Federal Rules of Evi-

- Associate Professor of Law, Southern Methodist University School of Law; A.B. 1965, Georgetown University; J.D. 1968, Villanova University; L.L.M. 1977, Harvard University.

1. The impact of the Federal Rules of Evidence, both as proposed and as enacted, has been profound. In 1974 the Uniform Rules of Evidence were amended to "reflect as closely as possible" the Federal Rules of Evidence. See UNIForm Rules of Evidence, Commissioners' Prefatory Note. Furthermore, as of January 1981, 21 states had adopted evidence codes patterned in whole or in part on the enacted or proposed Federal Rules of Evidence. See ALASKA R. Evid. 101-1101; ARIZ. R. EVID. 101-1103; ARK. STAT. ANN. § 28-1001 (1979); CoLo. R. EVID. 101-1103; Del. UNIform R. Evid. 101-1103; Fla. Stat. ANN. $\$ \$ 90.101-958$ (West 1979); HawaII Rev. STAT. § 626-1 (1980 Special Pamphlet); ME. R. Evid. 101-1102; MICH. R. Evid. 101-1102; MiNN. R. Evid. 101-1101; Mont. R. Evid. 101-1008; Neb. Rev. STAT. $\$ \$ 27-101$ to -1103 (1979); NEv. Rev. Stat. \$\$ 47.020-56.020 (1977); N.M. R. Evid. 101-1102; N.D. R. Evid. 101-1103; OHIo R. Evid. 101-1103; OkLA. STAT. ANN. tit. 12, $\$ \$ 2101-3103$ (West 1980); S.D. CodifIEd LAws ANN. $\S \S 19-9-1$ to -18-8 (1979); WASH. CT. R. (ER) 101-1101; WIS. STAT. ANN. $\$ \S 901.01-911.02$ (West 1975); WYo. R. Evid. 101-1104. 
dence, would promote uniformity and predictability of judicial treatment of the collateral-matter rule.

\section{The Collateral-Matter Rule}

The collateral-matter rule applies whenever one party seeks to introduce evidence to contradict the testimony of an opposing party's earlier witness. ${ }^{2}$ Generally stated, the rule forbids the introduction of extrinsic evidence to contradict a witness on a collateral matter. Its purpose is to limit the scope of impeachment to the introduction of evidence that is relevant to the important issues in dispute. The collateral-matter rule therefore functions as a corollary to the relevancy requirement; however, for pragmatic policy reasons, it excludes evidence that is logically relevant to the credibility of witnesses.

The test for the admissibility of evidence that contradicts prior testimony requires a determination of whether that testimony concerned a "collateral" matter. The most widely accepted definition of collateral matter derives from the 1847 English case of Attorney-General v. Hitchcock. ${ }^{3}$ Hitchcock was charged with the illegal use of an untaxed cistern to make malt. The prosecutor called a witness naned Spooner who testified to Hitchcock's use of the cistern. On cross-examination, Spooner was asked whether lie had told anyone that tax officers offered him twenty pounds to testify about Hitchcock's illegal activities. Spooner denied that lie liad inade such a statement and rejected any suggestion that he had received a bribe. ${ }^{4}$ The defense then attempted to introduce the testimony. of its own witness, Cook, that Spooner had told him that the tax officers had offered Spooner twenty pounds to testify agamst the defendant. The court sustamed the prosecution's objection to this testimony. The appellate court unanimously affirmed the trial court's ruling by holding that the matter on which the defense sought to contradict Spooner was collateral: whether Spooner had ever told anyone that he had been offered a bribe was not strictly relevant to whether Hitchcock had used the cistern. ${ }^{5}$ The court stated the test of collateralness as follows:

[I] $f$ the answer of a witness is a matter which you would be allowed on your part to prove in evidence-if it have such a connection with the issue, that you would be allowed to give it in evidence-then it is a matter on which you may contradict him. ${ }^{6}$

2. See C. MCCoRMick, Evidence $\$ 47$ (Cleary rev. 1972); 3A J. WiGMore, EvidenCE $\S \S 878,943,1000-07$ (Chadbourn rev. 1970).

3. 154 Eng. Rep. 38 (Exch. Ch. 1847). See J. WiGmore, supro note 2, § 1002.

4. 154 Eug. Rep. at 44 (Rolfe, B.).

5. Id. at 38 (Rolfe, B.).

6. Id. at 42 (Pollock, C.B.). 
Under this test, Cook's testimony had to be admissible during Hitchcock's case-in-chief, independent of Spooner's denial. For exainple, evidence that Spooner had taken a bribe would have been admissible apart from any denial by Spooner on cross-examination because it establishes a pecuniary interest or improper niotivation. ${ }^{7}$ Evidence that Spooner had been offered a bribe or had said as much before trial, however, has hittle bearing on whetlier Spooner was an impartial witness. ${ }^{8}$

The judges in Hitchcock recognized that evidence contradicting any part of Spooner's testimony under oath is relevant to some degree, even if it concerns a collateral inatter. ${ }^{9}$ The contradicting evidence, if believed by the jury, would show that Spooner had lied under oath, albeit on an inconsequential matter, and would obviously assist the jury in weighing the credibility of his testimony. ${ }^{10}$ The imposition of limitations on the admissibility of such evidence, then, must be justified.

The Hitchcock court stated three entirely pragmatic reasons in support of the collateral-matter rule. The first reason is to prevent unfair surprise to the witness; the court noted "the inconvenience that would arise from the witness being called to answer to particular acts of his life, which he might have been able to explain, if he had reasonable notice to do so."11 The second reason is to save time by avoiding prolonged inquiries into relatively unimportant matters. Consideration of "every possible question [that] might be suggested, for the purpose of seeing by such means whether the whole was unfounded," is simply impracticable. ${ }^{12}$ Finally, if much time is spent on matters not directly relevant to the central issues of the trial, there is an increased likelihood that the jury will become confused about the important issues. ${ }^{13}$ The collateral-matter rule theoretically moves trials to a speedy conclusion by denying lawyers the opportunity to cliase witnesses down every possible trail im the lope of ensnaring then in falsehood.

The pragmatic reasons for the collateral-matter rule offered in Hitchcock are not its sole justifications. Professor Wigmore developed a "logical reason" to explain why some attacks on a witness's credibility are permissible under the rule even though the precise testimony

7. See C. MCCormick, supra note $2, \S 41$ at 80 .

8. 154 Eng. Rep. at 43 (Pollock, C.B.).

9. Id. at $43-44$ (Rolfe, B.).

10. See generally J. WIGMORE, supra note 2, § 1008.

11. 154 Eng. Rep. at 44 (Alderson, B.). See generally J. Wigmore, supra note 2, § 1002.

12. 154 Eng. Rep. at 44 (Rolfe, B.).

13. See id. at 44 (Alderson, B.); J. Wigmore, supra note 2, § 1002. 
attacked can be literally defined as "collateral."14 Wigmore reasons that when the alleged testimomal error concerns an immaterial fact, the party who offers the contradiction asks the fact finder to infer from the error that other testimony by the witness concerning material facts is likewise in error. The ease with which the fact finder makes this inferential leap from the demonstrated immaterial error to an undemonstrated material error depends on the nature of the fact addressed by the contradicting evidence. Some contradictions reveal not only a discrepancy im the previous witness's testimony concerning an immaterial fact, but also the source of, or reason for the error. If the source of the immaterial error can logically serve as the source of material errors, then the contradictory testimony is admissible. In this mstance the contradictimg evidence aids the fact finder in inferring from the demonstrated immaterial error that more important parts of the witness's testimony may be incorrect. For example, suppose in the Hitchcock case that Spooner was asked on cross-examination whether he had ever been fired from a job by the defendant. Spooner denies it, but the defense brings on witness Cook to testify that he was present when the defendant discharged Spooner froin a job. If Cook's testimony is believed, it not only contradicts Spooner's denial but also reveals grounds for doubting Spooner's testimony incriminating the defendant. .

Furtherinore, continues Wigmore, even when the contradictimg evidence does not supply the reason for the error, it can still assist the trier of fact in inferring more important testimonial errors if the error concerns facts closely related in condition and circumstance to more important facts. ${ }^{15}$ In sucl a case the fact finder can easily and reasonably infer that whatever caused the error demonstrated by the contradicting evidence could also undermine the witness's testimony about more important facts. For example, assume that on direct examination Spooner testifies that he saw the defendant making malt in the cistern, and that the cistern was concealed in the defendant's barn. Suppose further that on cross-examination Hitclicock's barrister asks Spooner to describe the color of Hitchcock's barn. Spooner testifies that it is red. On rebuttal the defense calls an impartial witness familiar with the barn to testify that Hitchcock's barn always has been white-washed. According to Wigmore, the contradictory testimony should be admitted even though the fact revealed by the testimiony, the color of the barn, offers no explanation why Spooner lied or was mistaken. Nevertheless, because Spooner's observations of the barn and the cistern were closely

14. J. WigmoRE, supra note $2, \S 1001$.

15. Id. 
related in time and circumstance, the factfinder reasonably can infer from the error that Spooner had never seen Hitchcock's barn, and therefore had falsely accused him. ${ }^{16}$

Wigmore reduced the collateral-matter rule to a simple one-sentence test: "Could the fact, as to which error is predicated, have been shown in evidence for any purpose independently of the contradiction?"17 This test, however helpful, is somewhat opaque because it begs the following question: "Which facts are admissible independently of the contradiction?' "In this respect, Professor Maguire's statement of the collateral-matter test is inore complete:

Independent evidence may be given to prove a self-contradictory statement by a primary witness only if (a) the statement contradicts testimony by the primary witness about a matter directly in issue in the litigation, or (b) the statement contradicts testimony by the primary witness as to "those matters which affect the motives, temper, and character of the witness. . . with reference to his feelings toward one party or the other."18

Part (a) of the test is simply a statement of the most obvious fact about Anglo-American trials. When your adversary's witness has testified that fact $A$ is true, it is proper to offer testimony to contradict that point if the existence or nonexistence of fact $A$ will have a material effect on the outcome of the case. Evidence offered to rebut a fact asserted in defense of the suit also falls within category (a), matters directly in issue; the collateral-matter rule does not prevent the prosecution from offering such evidence. ${ }^{19}$ In these circumstances, it is difficult to contend that the contradicting evidence is not admissible

16. This aspect of Wigmore's "logical reason" rationale seems to correspond to McCormick's vaguely phrased "third type of allowable contradiction, namely, the contradiction of any part of the witness's account of the background and circumstances of a material transaction, which as a matter of human experience he would not have been mistaken about if his story were true." $C$. MCCoRMIC, supra note 2, $\$ 47$, at 99 (footnote omitted). A footnote supporting this quote is full of cxamples of this "linchpin of the story" type of contradiction. Id, n. 100. Wigmore treats this contradiction of an immaterial but key fact as noncollateral impeachment. See J. WIGMORE, supra note $2, \S 1005(\mathrm{f})$. However, as McCormick points out, this type of contradiction does not meet the test of noncollateralness espoused by Wigmore himself. See C. McCorMICK, supra note $2, \S 47$, at 99. This apparent anomaly is discussed in text accompanying notes 28-33 infra.

17. J. WIGMORE, supra note $2, \S 1003$, at 961 . Note that this definition of a noncollateral fact does not appear to permit contradiction of immaterial "key fact" or "linchpin of the story" testimony. Sce note 16 supra.

18. J. Maguire, Evidence: Common Sense and Common Law 67 (1947) (quoting Attorney-General v. Hitchcock, 154 Eng. Rep. 38, 42 (Exch. Ch. 1847) (Pollack, C.B.)).

19. See, e.g., State v. Gakin, 24 Wash. App. 681, 603 P.2d 380 (1979); Lunde v. State, 85 Wis. 80, 270 N.W.2d 180 (1978). Cf. People v. Mitchell, 402 Mich. 506, 518, 265 N.W.2d 163, 169 (1978) ("If a [murder] defendant were to claim, for example, that [the deceased's] homosexual overtures were shocking and offensive and that the reasonableness of [the defendant's] subsequent conduct should be assessed with that im mind, evidence of [the defendant's] comparable homosexual experience might tend to refute the claimed 'sense of outrage" "). 
"independently of the contradiction."20 When an attorney offers rebuttal testimony that contradicts a material fact, he offers it to disprove that fact, not merely to impeach the previous witness by contradiction. If the contradicting testimony were not probative of a disputed material fact, however, it would have no relevant purpose apart from impeachment by contradiction and it would be collateral.21 Thus, evidence of other uncharged crimes, wrongful acts,- or conduct offered to prove "motive, opportunity, intent, preparation, plan, knowledge, identity, or absence of mistake or accident"22 does not run afoul of the ban on extrinsic impeachment of collateral inatters. All of these proofs concern material issues regardless of when or by whom they are first raised at trial. 23

Part (b) of Maguire's formulation of the test refers to those facts that, if shown in contradiction, can call into question the contradicted witness's credibility. These independently admissible facts are readily categorized into those that demonstrate bias, ${ }^{24}$ lack of opportunity or capacity to perceive inaterial facts to which one testifies, ${ }^{25}$ corruption, ${ }^{26}$ or interest in the outcome of the case. ${ }^{27}$ These are facts that, under

20. J. WIGMORE, supra note $2, \S 1002$.

21. Cf. Harrell v. State, 593 S.W.2d 664, 668 (Tenn. Crim. App. 1979) (other-crime evidence offered to rebut the defendant's claim of ignorance that a crime was being committed held properly offered to prove a material element of the crime and to impeach witness); State v. Gakin, 24 Wash. App. 681, 603 P.2d 380 (1979) (evidence rebutting the defendant's claim of ignorance of how to drill open a safe was admissible as substantive evidence and to impeach the defendant by contradiction).

22. FED. R. EvID. 404(b).

23. In United States v. Gubelman, 571 F.2d 1252 (2d Cir.), cert. denied, 436 U.S. 948 (1978), in which the defense of a meat inspector charged with taking bribes was essentially one of mistaken identification, the court held there was no error in perimitting the prosecutor to introduce evidence of bribes taken by the defendant from four companies not charged in the indictment. Evidence of two of the uncharged bribes was adduced during the government's case-im-chief, and the remaining two were proved in its rebuttal case.

24. See, e.g., United States v. Harvey, 547 F.2d 720 (2d Cir. 1976) (trial court erroneously refused to permit defense witness to testify about the government witness's claim that the defendant had fathered her child and that she had vowed revenge). See also Umited States v. Haggett, 438 F.2d 396 (2d Cir. 1971).

25. See, e.g., United States v. Opager, 589 F.2d 799 (5th Cir. 1979). In Opager the court held that the trial judge erroneously excluded as collateral testimony evidence that the defendant and a government witness had not worked together at a particular salon during a certain period. This testimony would have disproved statements made by the government witness.

26. Cf. United States v. Honneus, 508 F.2d 566 (1st Cir. 1974), cert. denied, 421 U.S. 948 (1975) (error, albeit harmless, not to permit the defense to cross-examine government witness concerning witness's solicitation of a bribe from the defendant through an intermediary).

27. See, e.g., United States v. Frankenthal, 582 F.2d 1102, 1106-07 (7th Cir. 1978) (prosecution was permitted to contradict the denials of a defense witness that he had told the rebuttal witness that he "had a great deal riding on the outcoine of this proceeding" because evidence of bias or interest "is never collateral"). 
Wigmore's "logical reason," readily identify sources of potential testimonial error.

It should be noted that neither Wigmore's nor Maguire's formulation of the collateral-matter rule as drawn fron 1 Hitchcock accounts for everything that courts call noncollateral. For nistance, recall the hypothetical cross-examination of Spooner concerning the color of Hitchcock's barn. ${ }^{28}$ The rebutting testimony does not contradict the witness about a matter directly in issue, nor does it tend to prove bias, prejudice, corruption, or lack of ability or capacity to perceive. ${ }^{29} \mathrm{Mc}-$ Cormick concedes that this type of impeachment is collateral under the traditional test. ${ }^{30}$ Extrinsic contradiction of nonmaterial, linchpin facts can be justified as contradiction of "clearly connected" facts ${ }^{31}$ and therefore noncollateral impeachment under Wigmore's "logical reason" for the Hitchicock rule. The problem is that the courts' formulation of the Wigmore test ${ }^{32}$ does not appear to allow contradictions of nonmaterial, linchpin matters. Nevertheless, such contradictions can seriously undermine the witness' credibility, and inany courts permit them. ${ }^{33}$

When trial courts believe that justice would be served by permitting impeachinent despite a rule prohibiting it, they exercise discretion to ignore the collateral-matter rule and permit tle contradiction. ${ }^{34}$ And when appellate courts affirm such actions, the cases become impossible to reconcile and the rule itself difficult to recognize and apply. ${ }^{35}$ The next two sections illustrate some of the difficulties arising

28. See text accompanying notes 15-16 supra.

29. Contradiction of the statement regarding the color of the barn does not tend to show why the witness lied or was mistaken.

30. C. MCCoRMiCK, supra note $2, \S 47$, at 99 . See notes 16-17 supra.

31. J. WIGMORE, supra note $2, \S 1001$, at 958 .

32. See note 17 supra and accompanying text.

33. See J. Wigmore, supra note 2 , § 1003 , at $961 \&$ n.2.

34. See notes 224-25 infra and accompanying text.

35. E. Imwinkelrued, P. Giannelli, F. Gilligan \& F. Lederer, Criminal Evidence 55 (1979) ("The collateral fact rule is a confused area of law"). See cases cited in C. McCormick, supra note $2, \S 47$, at $99-100 \& \mathrm{n} .57$ ("This test is of nccessity a vague one because it nust meet an imdefinite variety of situations"); J. WIGMORE, supra note 2, \& 1003, at 962 ("Other courts are content to invoke simply the term collateral, and to decide according to the circumstances of each case"); Dolan, Rule 43: The Prejudice Rule in Evidence, 49 S. CAL. L. Rev. 220, 264 (1976) ("There is no doubt that the collateral question doctrine is . . the most dificult [concept] to deal with, often resembling a gestalt rule of evidence").

A major source of difficulty im the application of the collateral-impeachment rule is that extrinsic testimony that contradicts prior testimony often can be offered to prove several propositions simultaneously. Extrinsic evidence of a prior inconsistent statement is normally hearsay and admissible ouly to contradict the subject matter of the statement. However, if the hearsay exclusion does not apply, the prior inconsistent statement is admissible also to establish the truth of the matter asserted in the out-of-court statement. Extrinsic testimony about prior misconduct by the 
from attempts to apply the collateral-mater rule.

\section{Cross-Examination and Contradiction by "EXTRINSIC EVIDENCE"}

The collateral-matter rule prohibits contradiction of an opponent's witness with extrinsic evidence. A party may elicit a contradiction, even on collateral matters, ${ }^{36}$ from the witness himself on cross-examination, but the rule forbids the parading of witnesses to the stand to give the contradicting evidence. Thus, in the Hitchcock case, the defendant's counsel was allowed to cross-examine Spooner concerning his alleged pretrial statements about collateral matters, but, in the litigator's parlance, counsel had to "take" the witness's answers. ${ }^{37}$ The pragmatic underpinnings of the rule - the shortness of life and the length of court dockets--explain why it permits cross-examination but not extrinsic testimony concerning collateral facts. Attempts to elicit contradiction on cross-examination intrude only minimally on the efficiency of the trial. If the witness admits the error, the matter is finished, the trial moves on, and the jury can take the admitted error into account in assessing the witness's credibility. If the witness denies the error, little time is lost, for no rebuttal witnesses are allowed to contradict him on the collateral matter. Wigmore best states the nature of the rule: "It is not that the law of impeachment loves cross-examination more, but

witness may tend to prove the additional proposition that the witness is a person of bad character, unworthy of behief.

If the attacked witness is a party to the suit, the potential multiple uses of the misconduct evidence mcrease. Assume the witness to be contradicted is a criminal defendant charged with bribery of a public official and the prosecution offers evidence of uncharged bribes of officials by the defendant. There are two possible further uses of the evidence, one permitted and one not. If the evidence is offered to prove that the defendant has a tendency to obtain government contracts by bribery and that he, therefore, probably bribed the procurement officer in the instant case, then the evidence runs afoul of the rule excluding propensity evidence, i.e., evidence of a character trait to prove conduct in conformity therewith. See FED. R. EvID. 404(a)-(b). However, if the evidence tends to prove the defendant's intent, motive, opportunity, identity, plan, or design to bribe the official in the instant case, or that the defendant's giving of an item of value to the official was not mistaken or accidental, then the extrinsic evidence is admissible. See Fed. R. Evid. 404(b); C. MCCoRMICK, supra note 2, $\S 190$. The collateral-matter rule operates in a trial context in which there are many overlapping rules at work because of the many permissible and impermissible uses of the offered evidence. It is not surprising that, faced with an offer of extrinsic proof of the defendant's prior bad acts that have not resulted in a conviction, courts find it difficult to sort out quickly and accurately the permissible from the impermissible purposes for which the evidence is offered. Uncertainty about what the term "collateral" encompasses aggravates the complexity surrounding this determination.

36. See J. WIGMORE, supra note $2, \S \S 878,1006(2), 1023$.

37. See Attorney-General v. Hitchcock, 154 Eng. Rep. 38, 44 (Exch. Ch. 1847) (Alderson, B.). See also Hug v. United States, 329 F.2d 475, 483 (6th Cir.), cert. dented, 379 U.S. 818 (1964). 
that it loves extrinsic testimony less." 38

Allowing cross-examination but not extrinsic evidence on collateral points illustrates the anomalous fact that "collateral" and "irrelevant" are not coextensive terms. If collateral matters are irrelevant, they are not a proper subject even on direct examination. Thus, a collateral matter constitutes an area of imquiry that is not so irrelevant to preclude cross-examination, but not relevant enough to permit extrinsic proof. A good example of such an area is found in Federal Rule of Evidence 608(b). ${ }^{39}$ The rule permits cross-examination into specific instances of the witness's conduct that may demonstrate the untruthful character of the witness. ${ }^{40}$ For the same reasons that underlie the collateral-matter rule, however, the cross-examiner may not introduce extrinsic testimony to contradict the witness's demals of the instances of prior misconduct. The rule is designed to permit impeachment of witnesses by brief commando raids but not by full scale invasions on collateral poimts. The meaning of the term "extrinsic," however, is far from settled in the federal courts.

Some courts apply a broad definition of "extrinsic" when a witness is confronted on cross-examination with a document or other tangible evidence that tends to contradict him on an admittedly collateral point. For example, in United States $v$. Herzberg ${ }^{41}$ the prosecutor, while crossexamining the defendant, introduced imto evidence the report of a court decision to contradict the witness's demal that he had been sued by a particular person. The prosecutor called no witness of his own to introduce the case report. The Court of Appeals for the Fifth Circuit held that admission of the document was impermissible as impeachment with extrinsic evidence on a collateral matter. ${ }^{42}$.In United States $v$. Whitehead ${ }^{43}$ the trial court had ruled that if the defendant, an attorney charged with racketeering, took the stand, the prosecution would be

38. J. WIGMORE, supra note $2, \S 878$, at 648 .

39. FED. R. EVID. 608(b) provides:

Specific instances of conduct. Specific instances of the conduct of a witness, for the purpose of attacking or supporting his credibility, other than conviction of crime as provided in rule 609, may not be proved by extrinsic evidence. They may, however, in the discretion of the court if probative of truthfulness or untruthfulness, be inquired into on cross-examination of the witness (1) concerning his character for truthfulness or untruthfulness, or (2) concerning the character for truthfulness or untruthfulness of another witness to which character the witness being cross-examined has testified.

40. Sce, e.g., United States v. Cole, 617 F.2d 151 (5th Cir. 1980), cert. denied, 101 S. Ct. 3055 (1981) (prosecutor allowed, under rule 608(b), to ask the defendant about a false statement the defendant had made to a former employer).

41. 558 F.2d 1219 (5th Cir.), cert. denied, 434 U.S. 930 (1977).

42. Id at 1223-24. The court nevertheless held that admission of the report was harmless error and refused to reverse the conviction.

43. 618 F.2d 523 (4th Cir. 1980). 
allowed to introduce documentary evidence of the defendant's previous suspension from practice by the state bar for conduct involving deceit and misrepresentation. ${ }^{44}$ The Court of Appeals for the Fourth Circuit held that although the defendant could have been cross-examined concerning his suspension, the documents dealing with this suspension were not admissible because Federal Rule of Evidence 608(b) prohibits the use of extrinsic evidence of specific instances of conduct to prove untruthful character. ${ }^{45}$

It seems that the broad definition of extrinsic evidence used in these cases is wholly unnecessary. The policy reasons for excluding extrinsic evidence are the avoidance of undue prolongation of the trial, confusion of the issues, and unfair surprise to the witness. ${ }^{46}$ None of these policies is necessarily violated when a witness is confronted with nontestimomal evidence on cross-examination. If he is confronted with a document and admits its authenticity, the contradiction is coinpleted, swiftly and clearly. Recognizing the logic of this position, the Court of Appeals for the Third Circuit adopted a narrower definition of "extrinsic" in Carter v. Hewitt, ${ }^{47}$ a prison inmate's suit against guards who allegedly beat him. The plaintiff was confronted on cross-examination with a letter, admittedly written by him several months after the incident, that appeared to urge other inmates to file false reports of beatings by guards. The trial court permitted the letter to be introduced into evidence to impeacl the plaintiff's credibility. The Third Circuit affirmed, ruling that admission of the letter did not violate Federal Rule of Evidence 608(b) because the impeachment did not involve calling other witnesses to testify. When the extrinsic evidence comes from the witness himself the rule's "core concerns are not implicated."48 Therefore, the court stated, only when the attacked witness denies the

44. $I d$ at 528 .

45. Id. at 529. But see United States v. Kinnard, 465 F.2d 566 (D.C. Cir. 1972). In Kinnard the court reversed the trial court's ruling that a prosecution witness in a narcotics-sale case could not be forced to display his arms, revealing needle "tracks." The appellate court concluded that such evidence was not collateral but rather was probative of a motive of the witness to falsify his testimony and hence it bore directly on the question of the defendant's guilt. Id. at 573-74.

46. See notes 11-13 supra and accompanying text.

47. 617 F.2d 961 (3d Cir. 1980).

48. Id. at 969-70. Accord United States v. Senak, 521 F.2d 129 (7th Cir. 1975). In Senak the defendant, an attorney paid by the court to represent indigent criminal defendants, was charged with extorting fees fron his clients by threatening them with inadequate representation. Under cross-examination, the defendant claimed that the fee he received from one client was proper and, as such, he reported it on his income tax return. He then was confronted with his tax return in which the fee was not reported. The Court of Appeals for the Seventh Circuit held that the use of the tax return was a proper nonextrinsic attack on the defendant's cliaracter for truthfulness under FED. R. Evid. 608(b). 521 F.2d at 146. See also State v. Cervantes, 92 N.M. 643, 593 P.2d 478, (Ct. App. 1979). Cervantes held that asking a defendant witness to identify drug paraphernalia 
authenticity of the document and it is necessary to call additional witnesses to estabhish the admissibility of the document are the "core concerns" of the collateral-matter rule and rule 608(b) implicated. Only then would "these collateral matters assume a prominence at trial out of proportion to their significance." 49 When the impeaching document is either conceded by the attacked witness or self-authenticatimg, no trial time is lost, the witness is not surprised unfairly with an undocumentated allegation, and the danger of jury confusion is minimal because only a brief part of the trial is spent on the subject. ${ }^{50}$ And when the document or other nontestimonial evidence is not identified or conceded by the witness, the examiner must "take the answer" because the matter imquired about is collateral.

\section{The Direct Examination/Cross-Examination Distinction}

Conflictimg theories regarding the definition of "extrinsic" are not the only obstacle to a consistent and reliable application of the collateral-matter rule. Obviously the court must determine whether the matter to be contradicted is collateral. Problems develop when the matter sought to be contradicted originally arises on direct rather than on cross-examination. This section discusses the distinction and examines the various justifications for making exceptions to the rule when the matter is first raised on direct examination.

First, we inust distinguish the easy case. Courts encounter little difficulty in applymg the collateral-matter rule to matters first raised during cross-examination. When the cross-examiner seeks to call a witness to contradict the testimiony he elicited, the court, on objection, must apply the collateral-noncollateral test in deciding whether the contradicting witness may testify. But if the testimony that the witness is called to contradict was brought out on the direct examination of the first witness, the court's task is not so straightforward. In these situations courts have tended to apply the collateral-matter rule differently, as the following discussion demonstrates.

Theoretically, whether the point to be contradicted with extrinsic testimony arises on direct as opposed to cross-examination should have no effect on the rule's operation. Certainly the test of collateralness itself, i.e., whether the matter can be proved independently of the contradiction, does not expressly inake the direct-cross distinction an operative fact. The point of the test is that the matter need not have been

found in his home "is not proving specific conduct by extrinsic evidence." Id. at 651,593 P.2d at 486.

49. 617 F.2d at 970.

50. Id. at 971 ; J. WIGMORE, supra note $2, \S 979$. 
raised at all before the extrinsic proof is offered. Wigmore argues that extrinsic contradiction of collateral matters first raised on direct examination should not be permitted because, even though the witness can no longer claim unfair surprise, there is still the risk of confusion of issues. $^{51}$ Furthennore, if a witness opened the door to contradiction on everything said during direct, trials would go on forever. ${ }^{52}$ Nevertheless, Wigmore notes disparagingly a solid line of state and federal cases that hold that if a witness testifies to a certain fact on direct examination, the opposing side may introduce witnesses to prove the fact's falsity regardless of whether it is collateral. ${ }^{53}$ The cases adopting this exception justify it in a number of ways. Altlough the reasons are interrelated to greater or lesser degrees, they can be distimguislied by close examination of the cases and of the courts' language.

\section{A. Justification of the Exception by "Definitional Stop."}

The first ground for permitting the contradiction of all matters raised on direct seems to rest on an altered definition of the collateralmatter rule itself. For example, a 1925 Montana case ${ }^{54}$ simply held that "the rule prohibiting rebuttal and impeachment on a collateral matter is confined to inatters brought out on cross-examination." 55 The court gave no reason for apparently excepting all matters raised during direct examination from the prohibition of contradiction witl extrinsic testimony. The Montana court cited two of its earlier cases and Wharton's Criminal Evidence treatise ${ }^{56}$ in support of its ruling. ${ }^{57}$ Wharton also espoused this position in his Law of Evidence treatise, ${ }^{58}$ but he provides scant explanation for his narrow view of the rule. He cites two cases, only one of which directly supports his view that the collateral-matter rule applies only to testimomial evidence introduced during cross-examination. ${ }^{59}$ In neither of these cases did the courts cite au98.

51. J. WIGMORE, supra note $2, \S 1007$, at 980 . See also C. MCCormick, supra note $2, \S 47$, at

52. Powell v. State, 260 Ark. 381, 384, 540 S.W.2d 1, 2 (1976) ("Without the restriction on collateral matters a simple trial could be carried on for years").

53. J. WIGMORE, supra note $2, \S 1007$, at 979 n.1 (citing two federal and eleven state cases).

54. State v. Mott, 72 Mont. 306, 233 P. 602 (1925).

55. Id. at $311,233 \mathrm{P}$. at 604 . The facts of this case could have yielded an argument that the matter at issue was not collateral; however, the court held that the matter at issue was collateral.

56. F. WHARTON, LAW OF EVIDENCE IN CRIMINAL IsSUES $\$ 484$ (8th ed. 1880).

57. State v. Mott, 72 Mont. 306, 311, 233 P. 602, 604 (1925).

58. 1 F. Wharton, The LAW of Evidence $§ 559$, at 535 (1877).

59. The two cases are State v. Sargent, 32 Me. 429 (1851) and Whitney v. City of Boston, 98 Mass. 312 (1867). In Sargent the issue concerned the preparatory phase of a criminal act. Although the court expressed doubt whether such a matter could ever be considered inmaterial or collateral, it held that because the matter was not first raised on cross-examination, the rule 
thority or give reasons supporting their conclusions. ${ }^{60}$

One possible reason why some courts hold that the collateral-impeachment prohibition applies only to facts that are both collateral and brought out on cross-examination may stem from a narrow reading of precedent. Because the questions on appeal usually arise in a trial context in which the cross-examiner first elicits the fact later sought to be contradicted, the appellate court decisions generally state the rule in terms of that context: "It has long been held tliat a witness cannot, for the purpose of impeaching him, be contradicted on immaterial or collateral matters brought out on cross-examination."61 Later courts and commentators inay have interpreted the factual context of these holdings as a substantive limitation on the rule itself.62

This reasoning leads students of the rule to a dead end; it applies a "definitional stop" to further argument. It focuses not on the collateralness of the matter to be contradicted, but on the point during the trial at which the matter is raised. The "definitional stop" is the weakest justification for the exception.

against extrinsic contradiction of collateral matters did not apply, and that the exclusion of the testimony was error. $32 \mathrm{Me}$. at $430-31$.

In Whitney the court held that the contradiction did not concern a collateral point, but rather affected the "weight and value" to be given to the first witness's testimony. 98 Mass. at 316.

60. State v. Sargent, 32 Me. 429 (1851), illustrates McCormick's theory that "linchpin" facts are not collateral and, therefore, may be contradicted by extrinsic proof. C. MCCoRMICK, supra note $2, \S 47$, at 99 . Whitney v. City of Boston, 98 Mass. 312 (1867), on the other hand, was questionably cited by Wharton. The matter on which the plaintiff's witness, an expert real estate appraiser, was contradicted was raised on cross-examination. Id. at 314. Whitney falls more coinfortably into the category of cases holding that an expert witness's specific prior errors may be shown, in the discretion of the court, by extrinsic proof when they tend to demonstrate the expert's failure to possess a special qualification or to exercise the degree of skill necessary to testify as an expert. See Wilson v. Granby, 47 Conn. 59, $75-76$ (1879); J. WIGMORE, supra note 2, §§ 991, 1005 (d), at 922,969 . Wigmore is understandably vague, given the lack of uniformity among the courts, about whether such matters are collateral or whether contradiction should be allowed. He states in section 1005(d): "Particular instances of error indicating lack of expertness are usually not provable by extrirsic testimony, while circumstances other than these, diminishing the witness' qualifications, may perhaps be thus proved . . . . Such facts, therefore, may or may not be provable in contradiction." Id. \& 1005 (d), at 969.

61. State v. Curtis, 108 Kan. 537, 541, 196 P. 445, 447 (1921). See also Carpenter v. Ward, 30 N.Y. 243, 245 (1864) ("But to entitle the [cross-] examining connsel to show this discrepancy for the purpose of impeaching the credibility of the witness, it must either appear that the testimony related to a point material to the issue of trial, or to a fact brought out on the examination of the adverse counsel") (emphasis in original).

62. E.g., United States v. Lambert, 463 F.2d 552, 557 (7th Cir. 1972) ("The general rule is that a witness may not be impeached by contradiction as to collateral or irrelevant matters elicited on cross-examination"). 


\section{B. The Quasi-Estoppel Justification for the Exception.}

Many of the cases permitting the contradiction of collateral matters raised on direct examination speak in terms of quasi-estoppel. Because the witness "opened the door," he is im no position to complain when the adverse party seeks to disprove the testimony. ${ }^{63}$ A typical exainple is People v. Roemer, ${ }^{64}$ a inurder case in which the defendant took the stand. His counsel asked if he had ever been charged with killing anyone, and Roemer answered that he had not. On cross-examination the prosecutor atteinpted to contradict the defendant's assertion. It is not clear from the opinion whether the prosecutor imtroduced extrinsic evidence of a previous unurder charge, but the court stated in dicta that "the defendant had opened the door and invited the inquiry by his own testimony and it becaune permissible to refute that testimony by direct evidence to the contrary."65 Under any formulation of the Hitchcock rule, it is collateral that Roemer had been previously charged with an unrelated murder. Additionally, the prior accusation is not admissible as evidence of the defendant's bias, interest, or lack of opportunity or capacity to perceive relevant facts. ${ }^{66}$ Nor was the prior murder charge relevant to any substantive issue in the case. Hence, the prior charge was not independently admissible by the prosecution apart from the contradiction. The defendant's raising of the subject, however, made it a valid area of inquiry.

Two possible rationales explain the development of this quasi-estoppel theory. Wiginore suggests the first. ${ }^{67} \mathrm{He}$ states that before all the reasons for the Hitchcock rule had crystallized in court decisions, it was thought that the ban on collateral contradiction existed only to prevent surprising the witness. Thus, if the witness originally raised the matter at trial, the rule loses its rationale. Wigmore observes that the other policy reasons-saving time and avoiding confusion of the jurycontinue to weigh against collateral impeachment regardless of whether the facts to be contradicted are elicited on direct or on crossexamination. ${ }^{68}$

A second possible rationale for the quasi-estoppel theory is that if a party introduces certaim testimony to sustain its side of an issue, that

63. See Graham, Evidence and Trial Advocacy Workshop: Waiver of Right to Object Other Than by Failure to Make Objection-The Concept of "Door Opening," 16 CRIM. L. BULL. 461, 46465 (1980).

64. 114 Cal. 51, 45 P. 1003 (1896).

65. Id. at $55,45 \mathrm{P}$. at 1003.

66. See text accompanying notes 24-27 supra.

67. See J. Wigmore, supra note $2, \S 1007$, at 979.

68. Id. See also C. MCCormick, supra note 2, § 47, at 98. 
party should be precluded from denying the materiality of such testimony in attempting to prevent its contradiction. ${ }^{69}$ If this rationale implies that everything that is said on direct examination is relevant to a disputed material issue, then it completely ignores the reality of witness testimony at trial. Normally, some of a witness's testimony relates to his personal background and to facts giving color and dimension to the material testimony. For example, before an eyewitness to a traffic accident recounts what he observed, he usually describes who he is and where he was going at the time of the incident in question. Although these matters are collateral to the issue of who caused the accident, they are nevertheless properly adduced on direct examination. ${ }^{70}$ The collateral-matter rule rests on the assumption that it is worth the time, effort, and possible confusion to permit some but not all of the direct testimony to be contradicted. To permit the contradiction of all direct testimony under this justification, however, ignores the rule and undermines its sound rationales.

\section{The Curative-Admissibility Justification for the Exception.}

Another frequently asserted justification for permitting the extrinsic contradiction of direct testimony not strictly material to a disputed issue is the doctrine of "curative admissibility." parallels the other justifications voiced by the courts for not applying the collateral-matter rule to assertions inade on direct examination. The distinguishing focus of the curative-admissibility doctrine is that a party who gaims an advantage through the introduction of nonmaterial evidence may not complain when the other party offers nonmaterial evidence to offset that advantage. This concept of "invited error" requires the court to examine several elements to determine whether otherwise inadmissible evidence properly entered the case. These eleinents are: how the inadmissible evidence got in; whether the other party objected in a timely fashion to its introduction; how prejudicial

\footnotetext{
69. See Grimes v. Hill, 15 Colo. 359, 365, 25 P. 698, 700 (1891).

70. The fact to which the evidence is directed need not be in dispute. While situations will arise which call for the exclusion of evidence offered to prove a point conceded by the opponent, the ruling should be made on the bases of such considerations as waste of time and undue prejudice (see Rule 403), rather than under any general requirement that evidence is admissible only if directed to matters in dispute. Evidence which is essentially background in nature can scarcely be said to involve disputed matter, yet it is universally offered and admitted as an aid to understanding.
}

FED. R. Evid. 401, Advisory Committee's Notes.

71. This term is Wigmore's. $1 \mathrm{~J}$. Wigmore, Evidence $\S 15$ (3d ed. 1940). See 1 D. LouISELl \& C. MUELler, Federal EvidenCe § 11 (1977); Graham, supra note 63, at 461-65. 
the improper evidence was; and how prejudicial the rebutting proof will be.72

An exanple of a typical curative-admissibility case is Walker $\nu$. Trico Manufacturing Co. ${ }^{73}$ in which the manufacturer of a inachine rebutted the plaintiff's evidence of the "state of the art" with testimony that had no relevance to its defense of the products liability action. The Court of Appeals for the Seventh Circuit assumed that plaintiff's stateof-the-art evidence prejudiced the defense and reasoned that the defendant therefore was entitled to offset the evidence with irrelevant and prejudicial evidence of its own. ${ }^{74}$ The court held that because "[t]lue plaintiff opened this inatter during the presentation of her case in chief .. . she cannot complain of Trico's attempt at rebuttal."75

The doctrine of curative admissibility should be limited, at least conceptually, to cases like Walker in which the admission of rebuttal evidence is justified to counteract prejudicial inadmissible evidence introduced by the other side. In other words, fire inust fight fire. ${ }^{76} \mathrm{How}-$ ever, courts use the invited-error concept mucl inore broadly: to uphold the introduction of otherwise inadmissible rebuttal evidence to contradict collateral but not clearly inadmissible testimony.

\section{The Character-in-Evidence Justification for the Exception.}

The final justification for the exception to the collateral-matter rule is closely related to the curative-admissibility doctrine. It is based on the same equitable notion that once a party injects an issue into the case, he bears the risk that the other side will exact a heavy price for his having done so. These cases tend to concern direct testimony by the defendant that the court believes "place[s] his character in issue."77 In such cases, the courts do not mean that by testifying, for example, that he has never been in trouble with the law, a defendant makes his character an "essential element" of his defense. ${ }^{78}$ They inean only that the defendant has offered evidence of his good character as circumstantial

72. See C. MCCormicK, supra note $2, \S 57$, at 131 . See also 1 D. Louisell \& C. Mueller, supra note $71, \S 11$.

73. 487 F.2d'595 (7th Cir. 1973), cert. denied, 415 U.S. 978 (1974).

74. 487 F.2d at 600. See United States v. Doran, 564 F.2d 1176, 1177 (5th Cir. 1977), cert. denied, 435 U.S. 928 (1978). In Doran the court held that the defendant's direct testimony that he had refused a government plea bargain because he was innocent "invited" the prosecutor's crossexamination imto the defendant's withdrawn counter-offer to plead guilty.

75. 487 F.2d at 600 .

76. McCormick titles the section of his treatise that deals with this topic, "Fighting Fire with Fire: Inadmissible Evidence as Opening the Door." C. MCCoRMICK, supra note 2, \& 57, at 131.

77. See, e.g., United States v. Bowe, 360 F.2d 1, 14 (2d Cir.), cert. denied, 385 U.S. 961 (1966); State v. Patton, 593 S.W.2d 913, 920 (Tenn. 1979) (dissenting opimion). See also note 85 infra and accompanying text.

78. See FED. R. Evid. 405(b). 
evidence of his innocence. ${ }^{79}$ Criminal defendants are permitted to introduce this type of evidence, ${ }^{80}$ but the defendants usually are restricted to proof in the form of reputation or opinion testimony from "character witnesses." 81 Although trial courts technically would be correct in sustaining an objection to testimony by a criminal defendant concerning his previous law-abiding habits, they rarely do so, perhaps because of the same leniency toward the criminal defendant that produced the rule permitting him to introduce favorable character evidence in the first place.

Assuming, as the courts seein to do, that a defendant can testify to his own good character in defense of a criminal charge, the next question is whether he thereby opens himself to contradiction with extrimsic evidence. It is relatively clear that once a defendant has introduced evidence of a pertiment character trait, the prosecution may attack his character. ${ }^{82}$ However, under the Federal Rules of Evidence proof of specific instances of conduct intended to disprove the trait portrayed by the defendant's evidence is limited to cross-examination. ${ }^{83}$ Extrinsic rebuttal evidence, such as testimony by other witnesses, is permitted, but such evidence is restricted to reputation or opinion form of proof. ${ }^{84}$ Therefore, when a defendant makes a claim on direct that may be regarded as character evidence, the defendant may be cross-examined about specific instances of conduct that are relevant to the trait presented, but he should not be contradicted by extrinsic proof of prior misconduct. Nevertheless, courts permit the imtroduction of extrinsic evidence of prior criminal acts to rebut such self-portrayals of good character. $^{85}$

79. 2 D. Loulsell \& C. MUelleR, supra note $71, \S 138$ (Supp. 1981).

80. FED. R. Evid. 404(a)(1).

81. See id 405(a).

82. See id. 404(a)(1).

83. Id. 405(a).

84. Id.

85. For example, in United States v. Bowe, 360 F.2d 1 (2d Cir.), cert. denied, 385 U.S. 961 (1960), the court held that the prosecution properly introduced two rifles and several clips of ammunition, taken from defendant at his arrest, to contradict his direct testimony in which he portrayed himself as vigorously opposed to violent action. Cf. United States v. Giese, 597 F.2d $1170,1188-91$ (9th Cir.) (prosecution had the right to cross-examine the defendant on the contents of a book entitled "From the Movement Toward Revolution" after the defendant liad testified on direct about the contents of other books he had read to show his reading habits and his peaceable character), cert. denied, 444 U.S. 979 (1979).

Both McCormick, in the 1978 supplement to his evidence treatise, C. MCCoRMICK, supra note 2, $\S 191$, at 59, and Louisell and Mueller, in 2 D. Loursell \& C. MUELLER, supra note 71, $\S 138$, at 49 (Supp. 1981), note that a defendant's testimony that he is not the type of person who would commit the crime charged may open the door to rebuttal evidence. However, the authority they cite for the proposition that the defendant can be attacked by extrinsic prior-crimes evidence is limited to Bowe and a federal habeas corpus case in which the court applied the Pennsylvania 
The foregoing discussion of the collateral-inatter rule demonstrates the difficulty of its application. The federal courts im particular display an unfocused and frequently maccurate understanding of the rule, especially since the advent of the Federal Rules of Evidence. The following sections discuss the common law collateral-matter rule in the context of the Federal Rules of Evidence, focusing on one type of exception-what this article calls the "sweeping-claims" exception.

\section{The Sweeping-Claims Exception to the Collateral- MATTER RULE}

Just beyond the borders of the curative-admissibililty doctrine are the cases in which a witness inakes an "overly broad" 86 statement of fact on direct exammation. Often, the witness is a criminal defendant who makes a false sweepimg denial of any previous wrongdoing. Invariably, the other side does not object to the assertion, choosing instead to exploit this vulnerability by ineans of contradicting testimony. In short, the other side seizes a prime opportunity to prove that the witness is a perjurer. When the other party calls its contradicting witness, the proponent of the first witness nornally objects to the rebuttal testiinony, and the judge nust decide the poimt of law. The rebutting evidence of, for example, prior wrongdoing by the witness (but not his prior criminal convictions), should be excluded under the collateralnatter rule. The evidence is not admissible imdependently of the contradiction either to prove or to disprove a material fact, or to prove a fact that calls into question the witness's credibility. The evidence does not demonstrate a prior criminal conviction, and the point to be contradicted is not the factual "linchpim" of the witness's entire testimony. Thus, the collateral-inatter rule dictates the exclusion of the extrinsic contradiction. ${ }^{87}$ The black-letter rules of evidence provide that the op-

law allowing otherwise inadmissible prior convictions to impeach a defendant's sweeping claims of a blameless life. United States ex rel. Johnson v. Johnson, 531 F.2d 169 (3d Cir.), ccrt. denied, 425 U.S. 997 (1976). McCormick also refers the reader to the section of his treatise on curative admissibility. See C. MCCoRMICK, supra note $2, \S 57$. Thus, we are led from the rules governing the impeachment of character testimony to the principles of curative admissibility to justify the admissibility of specific mstances of conduct by extrinsic evidence.

Notice that when the defendant takes the stand in his own behalf and testifies to his good character, the government may attempt not only to rebut his character evidence, but also to impeach him as it would any other witness. See Unites States v. Bowe, 360 F.2d at 14; J. WIGMORE, supra note $2, \S \S 890,925$. However, the credibility of a witness is not open to attack by extrinsic evidence of specific instances of conduct. Sce FED. R. Evid. 608(b). See text accoinpanying notes 135-39 infra.

86. C. MCCoRMICK, supra note $2, \S 57$, at 132 n. 47 .

87. Both Wigmore and McCormick opine that the operation of the collateral-matter rule should not depend on whether the testimony to be contradicted is elicited on direct or on cross- 
ponent may cross-examine the witness concerning a statement made on direct and attempt to make the witness recant, ${ }^{88}$ but thc examiner may not contradict the testimony by calling other witnesses. In this type of case, however, the courts regularly permit the collateral contradiction. And, as this article shows, the reason for carving this sweepmg-claims exception out of the collateral-impeachment rule appears to be largely the same reason behmd the curative-admissibility doctrine: it is the fair thing to do under the circumstances. ${ }^{89}$ Despite the lack of any carefully articulated rationale, and despite the mability to fit neatly withm the confines of any evidentiary rule, the contradiction of sweeping statements on collateral points made during direct examination has blossomed into an accepted practice im the federal courts.

\section{A. The Development of the Sweeping-Claims Exception in the Federal Common Law.}

In a smattering of cases prior to 1954, a number of federal courts adopted the proposition that immaterial facts first raised on direct examination may be contradicted with extrinsic proof. 90 The reasons given for allowing such rebuttal were not uniform, ranging from no reason at all," to the familiar justification that the witness had "opened

examination. C. MCCORMICK, supra note 2, \$§ 47, 57 n.47; J. WIGMORE, supra note 2, § 1007. The courts have not heeded these learned professors in this context.

88. See C. MCCormick, supra note 2, § 47; J. Wigmore, supra note $2, \S 1006$.

89. See C. MCCoRMICK, supra note 2, § 47. In United States v. Beno, 324 F.2d 582 (2d Cir. 1963), the court commented:

It is true . . that where a defendant, in his direct testimony, falsely states a specific fact, the prosecution will not be prevented froin proving . . . by calling its own witnesses, that he hed as to that fact . . . . The rationale behind this rule is not difficult to perceive, for even if the issue injected is irrelevant or collateral, a defendant should not be allowed to profit by a gratuitously offered misstatement.

Id. at 588 (emphasis in original). In United States v.Winston, 447 F.2d 1236 (D.C. Cir. 1971), the court, referring to the doctrine of curative admissibility, explained, "Permission to explore in rebuttal with testimony not admissible on direct, on the ground that the other party has opened the doors, rest 'upon the necessity of removing prejudice in the interest of fairness.' " Id. at 1240 (quoting Crawford v. United States, 198 F.2d 976, 979 (1952) (footnote omitted)). See also Graham, supra note 63 , at $461-65$.

90. E.g., Atkinson v. Atchison, T. \& S.F. Ry., 197 F.2d 244, 246 (10th Cir. 1952); Brady v. United States, 148 F.2d 394, 395 (9th Cir. 1945); Peden v. United States, 54 F.2d 916, 917 (10th Cir. 1931); Citizens' Bank \& 'Trust Co. v. Allen, 43 F.2d 549, 551-52 (4th Cir. 1930). Wigmore incorrectly cites Union Pac. Ry. v. Reese, 56 F. 288 (9th Cir. 1893), as standing for this proposition. See J. WIGMORE, supra note $2, \S 1007$, at 979 n.l. The Reese court did not go that far in its holding because, as it noted, "Ip]laintiff's testimony as to his previous habits of sobriety was brought out on cross-examination, and was clearly a collateral inatter." 56 F. at 291.

91. In Peden v. United States, 54 F.2d 916 (10th Cir. 1931), a defendant charged with possession of an illegal still took the stand and testified on direct that he had nothing to do with the still in question, and that he neither knew how to make whiskey nor had even been around a still. The prosecutor impeached this testimony by producing a picture of the defendant at a different still 
the door."92 Other courts, conscious of the rule against extrinsic impeachment on collateral matters, simply stretched the definition of "noncollateral" to cover the inatter before them..$^{93}$

In 1954, however, the Supreme Court decided Walder v. United States, ${ }^{94}$ a case involving the fourth amendinent exclusionary rule and the "fruit of the poisonous tree" doctrine. The decision significantly advanced the development of the sweeping-claims exception to the point that Walder and the cases expanding on it ${ }^{95}$ now stand for the proposition that matters raised on direct examination may be contradicted by extrinsic evidence regardless of whether the matters are collateral. In Walder the venerable evidentiary rule against collateral impeachment found in Hitchcock and espoused by Wigmore and McCormick was partially echipsed by an einerging rule of constitutional criminal procedure. Today, it appears that the old principle is fast losing ground, especially im criminal cases. ${ }^{96}$

Walder was indicted for four sales of drugs to undercover narcotic agents. On direct examination, during his case-in-chief, he volunteered that he had never possessed, sold, or transferred narcotics. On crossexamination he reiterated this testimony and denied that a capsule of heroin was seized from his home two years before the transactions at issue. In rebuttal, the prosecution called witnesses who testified that heroin had in fact been seized from the defendant's hoine two years earlier. ${ }^{97}$ The Suprenne Court uplield the admission of the testimony concerning the prior narcotics seizure. The only question the Court

sometime earlier. The court held only that the picture was "clearly admissible for the purpose of contradicting his evidence. . . ." Id. at 917.

92. See, e.g., Brady v. United States, 148 F.2d 394 (9th Cir. 1945). In Brady the defendant was charged with concealing and transporting narcotics. On direct examination, he denied being an addict or ever having seen, purchased, or used narcotics. On rebuttal, the prosecutor called a witness who stated that while awaiting trial, the defendant underwent treatment for narcotic addiction under an assumed name. Affirming the conviction, the Court of Appeals for the Ninth Circuit stated, "Had this showing been offered merely to degrade the accused it would no doubt lave been improper to admit it, but appellant himself opened the matter up. Thus evidence of addiction became relevant and proper as rebuttal." Id. at 395 .

93. See, e.g., Citizens' Bank \& Trust Co. v. Allen, 43 F.2d 549, 552 (4th Cir. 1930). Only when a party attempts either to explain away facts imtroduced agamst liim, or to introduce evidence that tends to establish a defense, can it be said that evidence rebutting such explanation or such evidence is not collateral because it tends to disprove a defense. See, e.g., Scott v. United States, 172 U.S. 343, 346-48 (1899).

94. 347 U.S. 62 (1954).

95. See Oregon v. Hass, 420 U.S. 714 (1975); Harris v. New York, 401 U.S. 222 (1971).

96. United States v. Havens, 446 U.S. 620 (1980), discussed at text accompanying notes 17299 infra, is the most recent Supreme Court decision affecting this area.

97. The cliarges resulting from this earlier drug seizure were dismissed following a successful evidentiary suppression motion. 347 U.S. at 62-63. 
addressed was whether the federal exclusionary rule ${ }^{98}$ prevented the indirect use of tainted evidence. There was clear authority for Walder's contention that illegally seized evidence nnay never be introduced in a federal court for any purpose. ${ }^{99}$ It appeared that the case was controlled by Agnello $v$. United States, ${ }^{100}$ in which the Court disallowed the introduction of previously suppressed narcotics evidence in a fact situation identical to Walder, except that in Agnello the defendant's sweeping denial was first elicited on cross-examination. ${ }^{101}$ The Agnello Court disapproved of the prosecutor's actions on constitutional grounds, but its words sounded very much like those used by courts permitting extrinsic impeachment only of inatters first raised on direct:

In his direct examination, Agnello was not asked and did not testify concerning the [illegally seized and previously suppressed] can of cocaine. In cross-examination, in answer to a question over his objection, he said he had never seen it. He did nothing to waive his constitutional protection or to justify cross-examination in respect of the evidence claimed to have been obtained by the [illegal] search. ${ }^{102}$

Agnello is largely in accord with Attorney-General v. Hitchcock ${ }^{103}$ as a inatter of evidence law. ${ }^{104}$ The prosecutor asked Agnello on cross-examination if he had ever seen the can of narcotics before; this inatter was clearly collateral to the trial's central issues. ${ }^{105}$ The prosecutor

98. Evidence obtained in violation of the fourth amendinent, for example, in a warrantless search and seizure without probable cause, will be excluded at trial. The history of the rule is long and varied. See Mapp v. Ohio, 367 U.S. 643 (1961); Wolf v. Colorado, 338 U.S. 25 (1949); Weeks v. United States, 232 U.S. 383 (1914).

99. See Silverthorne Lunber Co. v. United States, 251 U.S. 385, 392 (1920) (Holmes, J.) ("The essence of a provision forbidding the acquisition of evidence in a certain way is that not inerely evidence so acquired shall not be used before the court, but that it shall not be used at all').

100. 269 U.S. 20 (1925).

101. Id. at 35 .

102. Id.

103. 154 Eng. Rep. 38 (Exch. Ch. 1847). See notes 3-13 supra and accompanying text.

104. See id. at 45.

105. The prosecutor also inquired whether Agnello had ever seen cocaine before. 269 U.S. at 29. The propriety of this broad question, in contrast to asking about the particular can of cocaine, is a close question that the collateral rule does not address. See text accoinpanying notes $36-40$ supra. The question implies prior criminal conduct by the defendant and thus is highly prejudicial. Before the enactment of the Federal Rules of Evidence, most federal courts probably would have excluded the question as improper evidence of "bad character" or criminal propensity because the prior dealimgs with narcotics did not result in a criminal conviction. See, e.g., United States v. Davenport, 449 F.2d 696, 699 (5th Cir. 1971); United States v. Rudolph, 403 F.2d 805, 806 (6th Cir. 1968); United States v. Pennix, 313 F.2d 524, 530 (4th Cir. 1963); Homan v. United States, 279 F.2d 767, 771-72 (8th Cir. 1960); United States v. Provoo, 215 F.2d 531, 535-37 (2d Cir. 1954). A court would probably reach the saine result under the Federal Rules of Evidence. See United States v. Blackshire, 538 F.2d 569, 572 (4th Cir.), cert. denied, 429 U.S. 840 (1976); FED. R. EvID. 608(b). 
should have had to "take" Agnello's negative answer. ${ }^{106}$ Thus, the prosecutor erred as a matter of evidentiary law, as well as a matter of constitutional law, when he contradicted Agnello with the suppressed evidencc. ${ }^{107}$ In Walder, the Supreme Court distinguished Agnello on the ground that Walder "[o]f his own accord, . . . went beyond a mere denial of complicity im the crimes of which he was charged and made the sweeping claim that he had never dealt in or possessed any narcotics." 108 The Court declined to rest its holding on the constitutionalwaiver concept mentioned in Agnello. ${ }^{109}$ Instead, it held that the defendant had abused the fourth ainendment's exclusiunary rule:

[T]o say that the defendant can turn the illegal method by which evidence in the Government's possession was obtained to his own advantage, and provide himself with a shield agaimst contradiction of his untruths [would] be a perversion of the Fourth Amendment.

He must be free to deny all the elements of the case against him .... Beyond that, however, there is hardly justification for letting the defendant affirmatively resort to perjurious testimony in reliance on the Government's disability to challenge his credibility. ${ }^{110}$

The Court apparently assumed that the federal common law of evidence did not prevent the prosecutor from contradicting Walder's "swccping claim" on direct."11 Although that assumption was arguably

It can be argued that Agnello's direct testimony that he did not recognize the matter he was carrying as cocaine made the broad cross-examination of Agnello concerning his prior familiarity with cocaine proper. However, even if this broad examination were permitted, the prosecutor, under the Hitchcock rule, would have been bound by the defendant's answers and would not have been permitted to offer contradicting extrinsic evidence. See cases cited at note 106 infra.

106. See Arpan v. United States, 260 F.2d 649, $659-61$ (8th Cir. 1958); McKenzie v. Unitcd States, 126 F.2d 533, 535 (D.C. Cir. 1942); McKune v. Umited States, 296 F. 480, 480 (9th Cir. 1924); Beyer v. Umited States, 282 F. 225, 226-27 (2d Cir. 1922); Rau v. United States, 260 F. 131, 136 (2d Cir. 1919).

107. Accord Mahoney v. United States, 26 F.2d 902, 903 (4th Cir. 1928) (improper contradiction of the defendant's cross-examination testimony with previously suppressed liquor found at defendant's home during her arrest).

108. 347 U.S. at 65.

109. See text accoinpanying note 102 supra.

110. 347 U.S. at 65 (footnote omitted).

111. See id at 65 n.3. Although a few federal precedents existed, see note 90 supra, the Walder Court did not cite thein. In support of its evidence law holding, the Court cited only the following quote from Michelson v. United States, 335 U.S. 469 (1948): "The price a defendant must pay for attenpting to prove his good name is to throw open the entire subject which the law has kept closed for his benefit and to make himself vulnerable where the law otherwise slields him." Id. at 479 . By preceding the citation with "Cf." the Court apparently rccognized that the quoted portion of Justice Jackson's opimion in Michelson addressed a completely different evidcntiary principle than that involved in Walder. Justice Jackson was referring to the rule that when a criminal defendant calls a character witness "to prove his good name" by means of his community reputation, the witness can be cross-examined about specific acts of misconduct, and even arrests of the defendant. See C. MCCorMICK, supra note $2, \S 191$. 
correct, ${ }^{112}$ the Court rushed by this evidentiary point in its haste to prevent a criminal defendant from abusing the exclusionary rule of the fourth amendment. Federal and state courts have cited Walder as authority for the rule of evidence that neither the exclusionary rule nor the Hitchcock rule prevents a party from using extrinsic proof to expose faisehoods volunteered by an opponent's witness during direct examination. ${ }^{113}$ The dual policy reasons supporting the Hitchcock rule in this context, judicial economy and the avoidance of jury confusion, were subordmated to the need to purge the trial process of perjury. ${ }^{114}$

The most anomalous result of Walder from an evidentiary perspective is that it spawned a widely accepted rule that illegal evidence may be used only when it contradicts the accused's direct testimony on collateral matters. Walder was impeached with extrinsic, tainted evidence on a matter collateral to the issue of his guilt im the case on trial.115 The Court stated in Walder that a defendant "must be free to deny all the elements of the case against him without thereby giving leave to the Government to introduce . . . evidence illegally secured by it." 116 Many federal courts concluded from this statement that a defendant may not be contradicted by illegal evidence that bears directly on his guilt or innocence. ${ }^{117}$ The courts, it seeins, completely lost sight

112. The editor of the 1981 supplement to $1 \mathrm{~J}$. WIGMORE, supra note $2, \S 15$, at 94 , in discussing Walder, states: "Mr. Justice Frankfurter's differentiation between the situation here presented with that of Agnello ... is not convincing. In both cases the evidence objected to involved credibility only; accordingly, the rule prohibiting contradiction on a collateral inatter is encountered . . . ." See Lee v. United States, 368 F.2d 834, 837 (D.C. Cir. 1966) ("Long before Walder . . . the rules of evidence . . . did not countenance the impeachment of witnesses by otherwise inadmissible evidence directed to collateral issues").

113. See notes $125-29$ infra and accoinpanying text.

114. The remaining policy reason for prohibiting extrinsic, collateral contradictions-to avoid unfairly surprising the witness with allegations of past misconduct, see J. WIGMORE, supra note 2, $\S 1002$ - obviously does not apply when the witness first raises the subject on direct.

115. Walder's past possession of narcotics was not offered nor was it admissible for any reason other than its contradiction of Walder's direct testimony. See C. MCCormick, supra note 2, $\$ 178$. Indeed, the trial court should have instructed the jury that the relevance of the "othercrimes evidence" was limited to the issue of the defendant's credibility. See, e.g., Jackson v. United States, 311 F.2d 686, 689-90 (5th Cir. 1963).

116. 347 U.S. at 65 .

117. E.g., Inge v. United States, 356 F.2d 345 (D.C. Cir. 1966). The court stated:

Since [Walder], we have held that an imadmissible statennent can be used only when the defendant inakes "sweeping claims" that go far beyond the crime charged, is impeached on a statement relating to "lawful proper acts" "collateral" to the issues before the jury, or is questioned about "minor points." In such situations, impeachment of the defendant affects only his credibility, since the truth of the impeaching stateinent does not itself tend to establish guilt.

Id. at 349 (footnotes omitted). See United States v. Caron, 474 F.2d 506 (5th Cir. 1973); United States v. Curry, 358 F.2d 904 (2d Cir. 1966); Johnson v. United States, 344 F.2d 163 (D.C. Cir. 1964); Tate v. United States, 283 F.2d 377, 381 (D.C. Cir. 1960) (Burger, J.) ("Once [the defendant] goes beyond denial of the crime itself and testifies as to collateral matters he is under an 
of the Hitchcock rule. The illegality of the evidence made it more readily admissible for impeachment purposes than it would have been had it not been unconstitutionally obtained. But the Hitchcock rule applies irrespective of whetler the contradicting evidence introduced on rebuttal was illegally seized. In fact, there is greater reason to exclude evidence when one considers the combination of the policies behind the federal exclusionary rule and the Hitchcock rule.

The life of this "impeachment on collateral points only" anomaly was summarily terminated in two brisk sentences by the Supreme Court in Harris v. New York. ${ }^{118}$ Harris's exculpatory direct testimony contradicted a statement, taken from him before he had been read his Miranda rights, ${ }^{119}$ that directly implicated him in the crime for whicls he was on trial. In upliolding the prosecutor's use of the statement on rebuttal, the Court noted:

It is true that Walder was impeached as to collateral matters included in his direct examination, whereas petitioner here was impeached as to testimony bearing more directly on the crimes charged. We are not persuaded that there is a difference in principle that warrants a result different from that reached by the Court in Walder. ${ }^{120}$

Thus, after Harris, illegally obtained evidence may be used to contradict a defendant's testimony on both collateral and noncollateral matters so long as the testimony to be contradicted is not "smuggle[d] . . . in on cross-examination,"121 as it was in Agnello. For inany courts, the Walder and Harris cases crystallized a rule of evidence as well as a rule of constitutional criminal procedure. When a criminal defendant makes statements on direct examination that the prosecutor stands ready to prove false, courts understandably apply Walder to allow the prosecutor to contradict those statements witl extrinsic evidence. ${ }^{122}$ If the contradicting evidence is constitutionally obtained, then so much the better. ${ }^{123}$ Not once was the collateral-1natter rule viewed as an impediment to impeachment on a collateral point raised on dircct exami-

added compulsion to tell the truth"). Conira, Groshart v. United States, 392 F.2d 172 (9th Cir. 1968). See also Comment, The Impeachment Exception to the Constitutional Exclusionary Rules, 73 Colum. L. ReV. 1476, 1489 (1973); Note, Impeachment by Unconstitutionally Obtained Evidence-The Erosion of the Exclusionary Rule, 34 OHIo Sr. L.J. 706, 715 (1973).

118. 401 U.S. 222 (1971).

119. See Miranda v. Arizona, 384 U.S. 436 (1966).

120. 401 U.S. at 225. Note that the author of the Harris decision, Chief Justice Burger, also authored Tate v. United States, 283 F.2d 377 (D.C. Cir. 1960), as a judge on the Court of Appeals for the District of Columbia Circuit. See note 117 supra.

121. Walder v. United States, 347 U.S. 62,66 (1954).

122. Sce notes 149-50 infra and accompanying text.

123. See United States v. Bell, S06 F.2d 207, 214 (D.C. Cir. 1974) ("Surely our obligation lto apply Walder within its prescribed limits] is not diminished by the circumstances that the evidence here is untainted"). 
nation, although the federal courts have otherwise applied the Hitchoock rule with vigor. ${ }^{124}$

Between the time of the Walder decision and the enactment of the Federal Rules of Evidence, ${ }^{125}$ this sweeping-claims exception to the collateral-impeachment rule received widespread judicial acceptance. Of course, in several federal drug cases in which the facts were similar to those in Walder, the exception was readily apphed. ${ }^{126}$ But Walder and Harris were not limited to their facts. They were interpreted as authorizing the use of evidence that is constitutionally infirm to "impeach exhorbitant [sic] testimonial claims volunteered by an accused on trial." 127 Nevertheless, the courts adhered to a rigid distinction be-

124. See, e.g., United States v. Leonard, 494 F.2d 955, 972 (D.C. Cir. 1974); United States v. Allende, 486 F.2d 1351, 1354 (9th Cir. 1973); United States v. Banks, 475 F.2d 1367, 1368 \& n.2 (5th Cir. 1973); Foster v. United States, 282 F.2d 222, 223 (10th Cir. 1960); Cwach v. United States, 212 F.2d 520, 530 (8th Cir. 1954).

125. Walder, decided in 1954, preceded by 21 years the enactunent of the Federal Rules of Evidence in 1975.

126. See United States v. Townes, 512 F.2d 1057, 1058 (6th Cir.) (defendant testified he had never had anything to do with drugs; he was properly impeached with illegally seized evidence that narcotics had been discovered in his trousers); cert. denied, 423 U.S. 846 (1975); United States v. Bell, 506 F.2d 207, 214-15 (D.C. Cir. 1974) (defendant testified he had seen narcotics only on television; he was properly impeached with evidence of an uncharged sale shortly before his arrest); United States v. Gonzalez, 491 F.2d 1202, 1204 (5th Cir. 1974) (the defendant denied on direct having ever sold cocaine; he was properly impeached by the testimony of a government witness with whom the defendant unsuccessfully had negotiated on the sale of half a kilogram of cocaine); White v. United States, 317 F.2d 231, 233 (9th Cir. 1963) (the defendant testified on direct that he had never been "involved in" and had never sold narcotics; he was properly impeached by testimony of a witness to whom the defendant had previously sold drugs); Jackson $v$. United States, 311 F.2d 686, 689-90 (5th Cir.) (defendant testified that he had nothing to do with narcotics in the previous four years; he was properly impeached by testimony of narcotics agents that defendant had stated to them he had recently transacted a narcotics deal and had a $\$ 50$ a day habit), cert. denied, 374 U.S. 850 (1963); Ferrari v. United States, 244 F.2d 132, 140 (9th Cir.) (defendant testified that he had not seen any narcotics "whatsoever" in the last year and a half; he was properly impeached by a witness who testified she had purchased narcotics from the defendant a "year and a half ago"), cert. denied, 355 U.S. 873 (1957).

One is tempted to doubt whether the defendants in the above cases received adequate representation from their trial counsels, who obviously had not read Walder or Harris before putting their clients on the stand.

127. United States v. Bell, 506 F.2d 207, 214 (D.C. Cir. 1974). See United States ex rel. Walker v. Follette, 443 F.2d 167, 170 (2d Cir. 1971). Follette, on the authority of Walder and Harris, upheld the admission of two prior convictions obtained when the defendant did not have benefit of counsel, to impeach the defendant's sweeping claim that he had never been convicted of a crime. See also United States v. Caron, 474 F.2d 506 (5th Cir. 1973) (illegal wiretap evidence perimitted to rebut defendant's sweeping claim); Compton v. United States, 334 F.2d 212 (4th Cir. 1964) (prosecution questions concerning illegally seized gambling paraphenalia permitted to impeach defendant's claim that she had never engaged in a numbers business); Smith v. United States, 312 F.2d 867 (D.C. Cir. 1962) (portions of defendant's indigency affadavit stating that a witness was needed to establish an alibi defense to a rape charge permitted to impeach credibility of defendant's testimony that prosecutrix had consented); United States v. Sing Kee, 250 F.2d 236 (2d Cir. 1957) (prosecutor permitted to show that the defendant invoked the fifth amendment in 
tween the contradiction of matters first raised on direct as opposed to on cross-examination. ${ }^{128}$ Agnello still had life and Walder and Harris did not affect the prohibition of contradiction of facts elicited durmg cross. The California Supreme Court best stated the rationale for the distinction: "[The] [d]efendant did not rely on the illegality of the impeaching evidence as a sword to commit perjury, but simply as a shield agamst the consequences of concededly improper police practices." ${ }^{129}$ In these circumstances extrinsic contradiction is improper.

\section{B. The Life of the Sweeping-Claims Exception Under the Federal Rules of Evidence.}

Simce the enactment of the Federal Rules of Evidence in 1975, the courts have had to determine whether the Rules intended to contmue or terminate the widespread post-Walder practice of permitting extrinsic impeachinent of sweeping claims. However, the rules and their draftimg history are imscrutable in this regard. The rules contain no provision which states in a coinprehensive way the ineans by which a witness's credibility may be impeached. 130 Only rules 608,609 , and 610 deal specifically with the subject, and they only treat impeachment by attack on the witness's character and religious beliefs. Rnle 613 clearly assumes that a witness may be self-contradicted by extrinsic evidence of a prior inconsistent stateinent. ${ }^{131}$ However, that rule does not make the admissibility of the statement dependent upon whether the matter contradicted is collateral or noncollateral. Nowhere do the rules mention the collateral-matter rule or the words "collateral" and "uncol-

front of the grand jury after the defendant testified at trial that his direct testimony was consistent with what he had told the grand jury).

128. See United States v. Mariani, 539 F.2d 915 (2d Cir. 1976); United States v. Blackshire, 538 F.2d 569 (4th Cir.), cert. denied, 429 U.S. 840 (1976); United States v. Trejo, 501 F.2d 138 (9th Cir. 1974); White v. United States, 349 F.2d 965 (D.C. Cir. 1965); accord, People v. Taylor, 8 Cal. 3d 174, 501 P.2d 918, 104 Cal. Rptr.350 (1972); People v. Rahming, 26 N.Y.2d 411, 259 N.E.2d 727, 311 N.Y.S.2d 299 (1970). See also C. MCCoRMICK, supra note 2, § 57; Comment, The Impeachment Exception to the Constitutional Exclusionary Rules, 73 ColuM. L. REv. 1476, 1485 (1973).

129. People v. Taylor, 8 Cal. 3d 174, 185, 501 P.2d 918, 925, 104 Cal. Rptr. 350, 357 (1972).

130. See S. Saltzburg \& K. Redden, Federal Rules of Evidence Manual 312 (2d ed. 1977).

131. FED. R. EvID. 613 provides:

(a) Examining witnesses concerning prior statement. In examining a witness concerning a prior inconsistent statement made by him, whether written or not, the statement need not be shown nor its contents disclosed to him at that time, but on request the same shall be shown or disclosed to opposing counsel.

(b) Extrinsic evidence of prior inconsistent statement of witness. Extrinsic evidence of a prior statement by a witness is not admissible unless the witness is afforded an opportunity to explain or deny the same and the opposite party is afforded an opportunity to interrogate him thereon, or the interests of justice otherwise require. This provision does not apply to admissions of a party-opponent as defined in Rule 801(d)(2). 
lateral". However, there is an allusion to the sweeping-claims exception to the collateral-matter rule in the drafting history of rule 609 , which involves impeachment with prior convictions. The Report of the Senate Committee states the following:

[T] he committee intends that notwithstanding this rule, a defendant's misrepresentation regarding the existence or nature of prior convictions inay be met by rebuttal evidence, including the record of such prior convictions. Similarly, such records may be offered to rebut representations made by the defendant regarding his attitude toward or willingness to commit a general category of offense, although demials or other representations by the defendant regarding the specific conduct which forms the basis of the charge against him shall not make prior convictions admissible to rebut such statement.

In regard to either type of representation, of course, prior convictions may be offered in rebuttal only if the defendant's statement is made in response to defense counsel's questions or is made gratuitously in the course of cross-examination. Prior convictions inay not be offered as rebuttal evidence if the prosecution has sought to circunvent the purpose of this rule by asking questions which elicit such representations from the defendant. ${ }^{132}$

Substitute the words "prior acts of misconduct not resulting in a conviction" for "prior convictions" and "records" in this quote, and it becomes an accurate statement of the federal case law concerning the contradiction of sweeping claims following Walder. Obviously this language reflects the Senate Committee's awareness of Walder and Harris and the impeachment practice they spawned. The Committee was seeking to ensure that the language of rule 609 would not be read as preventing otherwise inadmissible prior convictions froin being used to contradict gratuitous "misrepresentations" by defendants. It would seem clear, therefore, that the Senate Committee, at least, intended that the contradiction of volunteered sweeping claims should continue under the Federal Rules of Evidence. ${ }^{133}$

Nevertheless, the absence of any inore explicit recognition of the sweeping-claims exception in the rules and their legislative history has caused problems for courts faced with the sweeping-claim issue after enactment of the rules. And despite the fact that the rules were not intended to be a comprehensive restatement of the law of evidence for

132. S. REP. No. 93-1277, 93d Cong., 2d Sess. 14-15, reprinted in [1974] U.S. CODE CONG. \& AD. NEws 7051, 7061.

133. Conceivably this passage could be read as an attempt by the Senate Committee to restrict to prior convictions the items of proof that may be used to contradict a sweeping statement. However, no case or treatise reads the passage in this way. Moreover, the committee, no doubt, would lave been far more explicit if it liad intended to discard an evidentiary doctrine sanctioned by the Supreme Court. 
the federal courts, ${ }^{134}$ many courts have looked to a specific rule or cluster of rules in an attempt to pull the sweeping-claims exception into post-1975 practice. Before focusing on rule 607, which several courts have seen as the passport for engrafting the exception into post-1975 trials, the major stumbling block to its survival inust be examined.

Rule $608(b)^{135}$ permits, among other things, a cross-examiner to question a witness concerning specific instances of conduct which reflect adversely upon the witness's character for truthfulness. ${ }^{136}$ However, except for prior convictions admissible under rule 609, the crossexaminer must take the witness's answers and cannot prove prior conduct by extrinsic evidence. ${ }^{137}$ Thus, although rule 608(a) permits the introduction of extrinsic proof in the form of reputation or opimion evidence to attack credibility, ${ }^{138}$ rule $608(\mathrm{~b})$, in effect, declares that specific

134. See United States v. Alvarez-Lopez, 559 F.2d 1155, 1158 (9th Cir. 1977) ("The Evidence Code does not attempt to write a catalog of all the rules which govern evidence that can be used to impeach a witness. Rather, the code only attempts to lay down a few specific rules."). See also S. SALTZBURG \& K. REDDEN, supra note 130, at 313-14.

135. Fed. R. Evid. 608(b) provides:

Specific instances of conduct. Specific instances of the conduct of a witness, for the purpose of attacking or supporting his credibility, other than conviction of crime as provided in Rule 609, may not be proved by extrinsic evidence. They may, however, in the discretion of the court, if probative of truthfulness or untruthfulness, be inquired into on cross-examination of the witness (1) concerning his character for truthfulness or untruthfulness, or (2) concerning the character for truthfulness or untruthfulness of another witness as to which character the witness being cross-examined has testified.

The giving of testimony, whether by an accused or by any other witness, does not operate as a waiver of his privilege against self-incrimination when examined with respect to matters which relate only to credibility.

136. A witness's credibility may be called into doubt not only by showing bias or limited opportunity to observe, but also by demonstrating simply that the witness is not a trustworthy or believable person. This attack is on the witness's character. There are three forms that an attack on character inay take: (1) the witness's community reputation for untrustworthiness; (2) an individual's personal opinion about the witness's behevability; and (3) specific instances of misconduct. See FED. R. EviD. 608. Evidence of prior misconduct is a inethod of circuinstantially discrediting a witness by showing that the witness has demonstrated by past actions that he is not the type of person who should be believed. See C. MCCormick, supra note 2, \$\$ 41-43.

The two major questions the law nuust determine about this last type of "claaracter" evidence are (a) what types of prior misconduct may be put before the factfinder, and (b) in what manner may they be introduced. The answer to the first question depends on how strictly relevant the trait of veracity must be to the misconduct involved. Generally, the prior misconduct introduced to demonstrate the witness's bad character must be probative of the trait of untruthfuhiess. Thus, conduct showing the witness to be aggressive and violent is not admissible, whereas prior acts of fraud and deceit are admissible. See C. McCorMICK, supra note 2, § 42. Before the enactunent of the Federal Rules of Evidence, the majority of the federal courts forbade all inanner of inquiry into prior misconduct not resulting in a conviction when the imquiry's sole purpose was to discredit a witness. S. SALtzBuRg \& K. ReDDen, supra note 130, at 312. The rules limit inquiry, when permitted, to cross-examination; extrinsic testimony is not allowed to prove the misconduct. - FED. R. Evid. 608(b); C. MCCoRMICK, supra note 2, § 42. If the witness falsely denies engaging in previous misconduct, even an eyewitness to the misconduct may not contradict him.

137. See FED. R. Evid. 608(b).

138. FED. R. Evid. 608(a) provides: 
instances of conduct offered for this purpose are collateral inatters permitting no extrinsic proof. ${ }^{139}$

Problems arise when, in the typical case, a testifying defendant nnakes a sweeping denial on direct examination of some prior misconduct. 140 Of course, the sweeping-claims exception would permit contradiction by extrinsic evidence of prior misconduct even if the misconduct were collateral to the material issues at trial. But the first sentence of rule $608(\mathrm{~b})$ appears to say that such extrinsic rebuttal evidence would not be admissible, even if the defendant denied the misconduct on direct examination. Thus, Circuit Judge Kermedy in his dissent in United States $v$. Batts (Batts 1$)^{141}$ stated unequivocally that rule 608(b) had extinguished the common law sweeping-claimis exception. ${ }^{142}$ And in United States v. Burchinal ${ }^{143}$ the Court of Appeals for the Eighth Circuit intimated that rule 608(b) prohibited attempts by the

Opinion and reputation evidence of character. The credibility of a witness may be attacked or supported by evidence in the form of opinion or reputation, but subject to these limitations: (1) the evidence inay refer only to character for truthfulness or untruthfulness, and (2) evidence of truthful character is admissible only after the character of the witness for truthfulness has been attacked by opinion or reputation evidence or otherwise.

139. The reasons that justify the rule prolribiting extrinsic testimony concerning prior misconduct to impeach a witness are essentially the same as those that support the collateral-impeachment rule of Hitchcock. See J. WIGMORE, supra note 2, § 979.

It should be clear that the Hitchcock rule against collateral impeachments is not necessarily overlapped by rule 608(b). The Hitchcock rule excludes extrinsic proof offered to contradict a witness on a point collateral to any material issue in the case. The collateral matter exclusion is not limited, as is rule 608(b), to prior conduct by the witness, and may extend to any external fact, even the conduct of a third person. See, e.g., State v. Oswalt, 62 Wash. 2d 118, 381 P.2d 617 (1963). Under Hitchcock, the only criterion is whether the proof of the external fact contradicts the witness's testimony on a material point, or is otherwise admissible by that party apart from the contradiction. On the other hand, rule 608(b) does not specifically address impeachment by contradiction. Character evidence in the form of specific conduct offered to inpeach a witness's credibility is madmissible under the rule regardless of whether the witness has testified concerning the matter.

More often than not the extrinsic evidence would contradict the witness's testimony and also prove a prior act which is reflective of the witness's character for untruthfulness. Here the Hitchcock rule and rule 608(b) overlap. It is understandable then that federal courts which had einbraced the bastard sweeping-claims rule prior to the enactinent of the Federal Rules of Evidence in July, 1975, since then have had to confront the question whether rule 608(b) has eliminated it.

140. Recall, for example, that in Walder the defendant volunteered on direct that he had never possessed or sold narcotics. The rebuttal evidence was that Walder had indeed possessed drugs in the past. See text accoinpanying note 97 supra.

141. 558 F.2d 513, 519 (9th Cir. 1977) (Keunedy, J., dissenting), opinion withdrawn and new opinion substituted, 573 F.2d 599 (9th Cir.), cert. denied, 439 U.S. 859 (1978).

142. 558 F.2d at 522 n.6 (Keunedy, J., dissenting): "Before the enactment of the Federal Rules, we permitted extrinsic evidence on rebuttal to prove the falsity of a witness' statement on direct. [Citing Walder and other cases.] In hight of the express dictates of rule 608(b), this coinmon law rule of evidence has no continued validity in the federal courts." In his dissent in the revised opimion Judge Kennedy adhered to this position. See 573 F.2d at 604 n.1.

143. 657 F.2d 985 (8th Cir. 1981). 
defense to introduce extrinsic evidence that a government witness was continuing to deal in drugs after the charged conspiracy had ended, contrary to his testimony on direct examination. ${ }^{144}$

But this view is mistaken. Despite the misleadingly broad language of the rule, 145 its function is quite narrow. Rule 608(b) is intended, along with rule 609 , to govern the permissible scope of impeachment of a witness's credibility with the third of the three types of character evidence: reputation, opimion, and specific conduct (including prior convictions). This limitation excludes extrinsic evidence only when the sole purpose of the proof is to demonstrate by means of specific instances of conduct that the witness's character is such as to render him or her untrustworthy under oath. ${ }^{146}$ The rule does not prohibit extrinsic evidence offered to impeach the witness's credibility by one of the noncollateral modes of impeachment. ${ }^{147}$ Thus, if the specific instance of conduct would also demonstrate a witness's bias for, or prejudice against a party to the suit, then extrinsic proof of it is not precluded by rule $608(\mathrm{~b}){ }^{148}$

144. The court was less than clear on this point: "The question is arguably probative of [the witness's] truthfulness because [he] had earher testified that he last sold marijuana in Deceinber . . . ." Id. at 994. The court continued: "However, even if [he] had been questioned about and denied subsequent drug dealings the defense could not under Rule 608(b) offer any extrinsic evidence of such dealings." Id.

145. For example, the rule provides: "Specific instances of the conduct of a witness, [offercd] for the purpose of attacking . . . his credibility, other than a conviction of crime . . . , nay not be proved by extrinsic evidence." FED. R. EviD. 608(b).

146. Of course, where cross-examination is permitted under rule 608(b) into the prior conduct, and the prior conduct is denied by the witness, the rebuttal evidence also proves that the witness hed under oath on cross-examination. However, this additional purpose does not create sufficient reasons to permit the cxtrinsic contradiction.

147. Of course, prior conduct offered to prove, for example, intent, inotive, and plan under the second sentence of rule 404(b) inust also be distinguished.

148. In United States v. Ruiz Rios, 579 F.2d 670, 673 (1st Cir. 1978), the court spoke of "[t]he 'bias' exception to the strictures of Federal Rules of Evidence 608(b) and 609(a)." This statemcnt demonstrates a fundamental confusion concerning the scope of rule 608. Bias evidence is not character evidence, but several federal trial and appellate courts have failed to understand this distinction. In United States v. James, 609 F.2d 36 (2d Cir. 1979), cert. denied, 445 U.S. 905 (1980), the trial court excluded extrinsic evidence offered to show that a governinent witness may have had reason to beheve that his testifying in the instant case would cause him to receive lenient treatınent in a pending, unrelated case. Although it affirmed the conviction, the Court of Appeals for the Second Circuit accurately observed that rule 608(b)'s proscription of extrinsic proof does not apply to proof tending to show bias. Id. at 46. See United States v. Diecidue, 603 F.2d 535, 550 (5th Cir. 1979), cert. denied, 445 U.S. 946 (1980); United States v. Frankenthal, 582 F.2d 1102, 1106 (7th Cir. 1978); United States v. Harvey, 547 F.2d 720, 722 (2d Cir. 1976); Johnson v. Brewer, 521 F.2d 556, $562 \&$ n. 13 (9th Cir. 1975).

In United States v. Kelley, 545 F.2d 619 (8th Cir. 1976), cert. denied, 430 U.S. 933 (1977), the court reached the remarkable conclusion that evidence offered by the defense to show that two major prosecution witnesses directed threats and violence toward the defendants was inadmissible 
Notwithstanding the confusion wrought by the language of rule 608(b), the more perceptive federal court opinions have held that not only the collateral-matter rule of Hitchcock ${ }^{149}$ but also its sweepingclaims exception have survived the enactment of the Federal Rules of Evidence. ${ }^{150}$ Rule 607 is the rule most frequently used to justify the continued existence of the sweeping-claims exception. ${ }^{151}$ At first, this justification is difficult to understand because rule 607 inerely provides:

under Federal Rules of Evidence 607, 608 and 609. 545 F.2d at 622. It is difficult to conceive of stronger evidence of witness bias.

149. For example, in United States v. Opager, 589 F.2d 799, 803 (Sth Cir. 1979), the court stated:

[W] believe that Rule 608(b) should not stand as a bar to the admission of evidence introduced to contradict, and which the jury might find disproves, a witness's testimony as to material issues of the case.

The fact that the business records might have the incidental effect of proving [the governinent witness] a liar does not affect their admissibility as relevant evidence.

See also United States v. Cole, 617 F.2d 151 (5th Cir. 1980), cert. denied, 101 S. Ct. 3055 (1981); United States v. Herzberg, 558 F.2d 1219 (5th Cir.), cert. denied, 434 U.S. 930 (1977); United States v. Warledo, 557 F.2d 721 (10th Cir. 1977); United States v. Carrasquillo, 412 F. Snpp. 289 (E.D. Pa. 1976); Carlsen v. Javurek, 526 F.2d 202, 211 (8th Cir. 1975). However, some courts have incorrectly ruled, in effect, that rule 608(b) prohibits extrinsic contradiction on noncollateral issues. In United States v. Banks, 520 F.2d 627 (7th Cir. 1975), the court affirmed the decision of the trial court, which barred attempts by the defendant to put on testimiony that the government witnesses were drug addicts. Although the appellate court correctly observed that evidence of current drug use was relevant to possible impairment of the witness's ability accurately to recall and relate facts, it went on to declare cryptically that the application of rule 608(b) to exclude the evidence "will not work any injustice." Id. at 631. Because the evidence was not offered to impeach the witnesses' character but rather to demonstrate a possible infirmity of their testimony, rule 608(b) was inapplicable to the question. See also Marshak v. Green, 89 F.R.D. 637 (S.D.N.Y. 1981). In Marshak the court ruled that rule 608(b) prevented the admission of extrinsic evidence that the plaintiff and his attorney attenpted to bribe and coerce a witness to commit perjury at trial. Again, rule 608(b) applies to attempts to show noncredible character, not to possible admissions by conduct. See C. MCCormick, supra note 2 , §§ 42, 271.

150. The following cases have upheld the proposition that a false claim made on direct examination may be rebutted with extrinsic evidence: United States v. Green, 648 F.2d 587, 595 (9th Cir. 1981); United States v. Pantone, 609 F.2d 675, 680 (3d Cir. 1979); United States v. Herman 589 F.2d 1194, 1196 (3d Cir. 1978), cert. denied, 441 U.S. 913 (1979); United States v. Benedetto, 571 F.2d 1246, 1250 (2d Cir. 1978); United States v. Alvarez-Lopez, 559 F.2d 1155, 1157 (9th Cir. 1977); Umited States v. Wright, 542 F.2d 975, 980 (7th Cir. 1976), cert. denied, 429 U.S. 1073 (1977); United States v. Salvitti, 451 F. Supp. 195, 203 (E.D. Pa.), affd, 571 F.2d 573 (3d Cir. 1977). The following cases lield that the admission of extrinsic rebuttal evidence to contradict a witness's testimony on cross-examination was error, many of the courts clearly implying that if the testimony rebutted had been either elicited on direct examination or volunteered on cross, then the impeachment would have been proper. United States v. Havens, 592 F.2d 848 (5th Cir. 1979), rev'd, 446 U.S. 620 (1980); United States v. Herman, 589 F.2d 1191 (3d Cir. 1978), cert. denied, 441 U.S. 913 (1979); United States v. Herzberg, 558 F.2d 1219, 1223 (5th Cir.), cert. denied, 434 U.S. 930 (1977); United States v. Warledo, 557 F.2d 721 (10th Cir. 1977); United States v. McFadyen-Snider, 552 F.2d 1178, 1182 (6th Cir. 1977), cert. denied, 435 U.S. 995 (1978).

151. See, e.g., United States v. Pantone, 609 F.2d 675, 682 (3d Cir. 1979); United States v. Benedetta, 571 F.2d 1246, 1250 n.7 (2d Cir. 1978); United States v. Miah, 433 F. Supp. 259, 265-66 (E.D. Pa.), affd, 571 F.2d 573 (3d Cir. 1977); United States v. Carrasquillo, 412 F. Supp. 289, 292 (E.D. Pa. 1976). 
"The credibility of a witness may be attacked by any party, including the party calling him." 152 Nothing in the Advisory Committee notes leads one to believe that rule 607 is even remotely connected to the sweeping-claims exception. A closer reading of some of the courts' citations of authority for this puzzling conclusion reveals its likely source. Several courts cite Weinstein and Berger's highly influential treatise on the Federal Rules of Evidence, Weinstein's Evidence, to support their conclusion. In the section discussing rule 607, the authors decided, for less than obvious reasons, to discuss together the collateral-matter rule, contradiction of matters first raised on direct, and impeachment with illegally obtained evidence. ${ }^{153}$

Regardless of whether one slrould infer the federal practice governing impeachment by extrinsic contradiction on a collateral matter from a specific Federal Rule of Evidence, or whether it exists somewhere in the lacunae of the rules, there is no doubt that the federal courts, and inany state courts, permit sucl contradiction when the inatter arises as a sweeping claim on direct examination. A relatively early appellate decision that bridges the gap between pre-rules case law and post-rules adjudication is United States $v$. Benedetto. ${ }^{154}$ Benedetto was a federal meat inspector prosecuted for accepting bribes from four ineat processors. When the defendant took the stand he not only denied accepting any gratuities from the government's witnesses, but also declared that he had never accepted any bribes from anyone. ${ }^{15 s}$ On cross-examination, the prosecutor asked the defendant if he had accepted a bribe from a fellow employee of one of the defense witnesses. After the defendant denied the allegation, the prosecutor called the employee in rebuttal to testify that he had made periodic cash payments to Benedetto. ${ }^{156}$

The governinent souglit to justify the rebuttal evidence as relevant to prove the knowledge and intent of the defendant, as well as his iden-

152. FED. R. EVID. 607.

153. See 3 J. Weinstein \& M. Berger, WeInStein's EVIdence 1f 607[02], 607[05]-[06], 607[09] (Supp. 1981). A later treatise, S. SALTZBURG \& K. REDDEN, supra note 130, at 301, 30405 , also discusses impeachment with illegally seized evidence and prior inconsistent statements under the heading of rule 607. The latest treatise on the Federal Rules of Evidence deals with impeachment by contradiction and the collateral-natter rule under rule 611 . $3 \mathrm{D}$. LouiseLL \& C. MUELLER, supra note $71, \S 343$ (1979). The collateral-matter rule is also treated under rule 403.2 id. $\S 129$ (1978). Extrinsic impeachment of matters raised on direct is discussed under rule 608, 3 id. $\S \S 306,307$, and at 1 id. $\S 11$ (1977), covering rule 103 and the doctrine of curative admissibility.

154. 571 F.2d 1246 (2d Cir. 1978).

155. Id. at 1248.

156. Id. 
tity because it showed a continuing plan under rule 404(b). ${ }^{157}$ The court rejected these contentions, holding that the intent and knowledge of the defendant were not in issue at the trial, and that the evidence of other crimes was not unusual and distinctive enough to show identity through a common plan. ${ }^{158}$ The court also rejected the government's argument that the admission of evidence of other crimes was legitimized by the defendant's introduction of character testimony that he had not taken bribes. ${ }^{159}$

In the court's view, however, the defendant's testimony on direct examination that he had never taken bribes from anybody ultimately tipped the balance in favor of the government: "Once a witness (especially a defendant-witness) testifies as to any specific fact on direct testimony, the trial court has broad discretion to admit extrinsic evidence tending to contradict the specific stateinent, even if such statement concerns a collateral matter in the case." 160 The court also noted that Benedetto's sweeping denial was "closely intertwined with the central

157. Rule 404(b) states in full:

Evidence of other crimes, wrongs, or acts is not admissible to prove the character of a person in order to show that he acted in conformity therewith. It may, however, be admissible for other purposes, such as proof of motive, opportunity, imtent, preparation, plan, knowledge, identity, or absence of mistake or accident.

FED. R. Evid. 404(b).

158. $571 \mathrm{~F} .2 \mathrm{~d}$ at 1249. The court's holding that like-crimes evidence was not admissible as part of the government's case under rule 404 (b) amounts to a finding that the evidence was collateral.

159. Id. As the court points out, the trial court erroneously admitted the defendant's "good character" evidence. The appellate court noted that, under FED. R. EvID. 405(a), a defendant's good character may be proved only by reputation and opinion evidence. Reference to specific instances of conduct may be made only on cross-examination. Id. at 1250. Although the exact phrase was not mentioned in the court's summary of the government's contentions on appeal, the prosecution's arguments sound very much like a request that the court apply the doctrine of "curative admissibility" to uphold the introduction of the evidence. See text accoinpanying notes 71-76 supra. Without explanation, the court stated: "That the defense improperly attempts to establish defendant's good character by reference to specific good acts did not justify the prosecution's use of testimony concerning bad acts either in its direct case or in rebuttal." 571 F.2d at 1250 . The court supported this statement with a citation to United States v. Beh̆̈o, 324 F.2d 582 (2d Cir. 1963), in which the Beno court commented in a similar context:

[I] $\mathrm{t}$ makes hittle sense to insist that once incoinpetent evidence is erroneously admitted, the error inust of necessity be coinpounded by "opening the door" so wide that rebutting collateral, inflammatory and highly prejudicial evidence may enter the minds of the jurors. In short, a small advantage improperly obtained does not compel the exaction of a gross disadvantage in penalty, particularly where a tarnished verdict is the inevitable result.

Id. at 588-89. However, in Beno, in which an Internal Revenue agent charged with soliciting a bribe improperly introduced good-character evidence through specific-acts testimony, the government's rebuttal evidence addressed inatters totally foreign to the disputed issues, showing that the defendant had been arrested for reckless driving and forgery of tax returns. Id. at 585-86.

160. $571 \mathrm{~F} .2 \mathrm{~d}$ at 1250. 
issue" in the case, ${ }^{161}$ implying that although the rebuttal evidence concerned a collateral issue, it was not "too collateral." Therefore, the impeachment by contradiction was acceptable. In support of its holding, the court cited, inter alia, ${ }^{162}$ Federal Rule of Evidence 607, explaining that the rule "appears to allow the continuation of federal practice in admitting extrinsic evidence to impeach specific errors or falsehoods in a witness's direct testimony, subject to rule 403 considerations."163

The court did not mention rule 608(b), ${ }^{164}$ which bars extrinsic evidence of specific acts of misconduct that do not result in a conviction from being offered to attack credibility. If the court had found that either rule 608(b) or the collateral-inatter rule apphed, then the prosecutor would have been bound by Benedetto's denial on cross-examination that he did not take bribes from the government's rebuttal witness. It can be argued that rule 608(b) does not apply because the specificmisconduct evidence was not introduced as character evidence per se. Rather, the prosecutor offered it merely to contradict a fact to which the defendant freely testified on direct examination. Even if this argument is accepted, the rebuttal evidence runs afoul of the collateral-matter rule. The court in Benedetto correctly believed that evidence of crimes not charged in the indictment is collateral. ${ }^{165}$ Thus the Benedetto court upheld the specific contradiction of a witness's testimony on a collateral matter on the basis of the prior federal practice derived from Walder. The court missed an opportunity to examine the rationale for the practice within the framework of the newly enacted Federal Rules of Evidence. The sweeping-claims exception was simply incorporated into the rules via rule 607 , through the implied discretion of the courts to do what is fair during the trial.

Although the courts continue to justify extrinsic collateral impeachment in the same terms that they used before the enactinent of the Federal Rules of Evidence, for example, by simply defining matters raised on direct as not collateral, ${ }^{166}$ or by concluding that the volunteered falsehood "opened the door," 167 these terms are purely con-

161. Id.

162. The court also cited Walder v. United States, 347 U.S. 62 (1954), see notes 94-117 supra and accompanying text, and United States v. Beno, 324 F.2d 582 (2d Cir. 1963), see note 159 supra.

163. 571 F.2d at 1250 n.7.

164. For the text of the rule, see note 39 supra.

165. See text accompanying notes 83-84 supra.

166. See, eg., United States v. Alvarez-Lopez, 559 F.2d 1155, 1157 (9th Cir. 1977); United States v. Herzberg, 558 F.2d 1219, 1223 (5th Cir.), cert. denied, 434 U.S. 930 (1977).

167. See, eg., United States v. Benedetto, 571 F.2d 1246, 1250 (2d Cir. 1978); United States v. Miah, 433 F. Supp. 259, 265 (E.D. Pa.), affd, 571 F.2d 573 (3d Cir. 1977). Cf. United States v. Wright, 542 F.2d 975, 980 (7th Cir. 1976), cert. denied, 429 U.S. 1073 (1977) ("Having denied that 
clusory and beg justification. Nevertheless, the cases do evince a "sense" of the judges' main concern-the jury. It is not just that perjury may go unmasked, but rather that the jury may be misled. The rules of evidence are the products of compromise, wherein coinpeting mterests are juggled to achieve a precarious balance. Not all relevant evidence is admitted. Not all falsehoods are permitted to be pursued. Many of the rules are based upon a judgment, or simply fear, that the jury may be sidetracked from their main pursuit or stampeded into another if certaim evidence is admitted. Hence courts are willing to hold the collateral-matter exclusion in abeyance when they think it necessary to set the jury straight. This notion is reflected most clearly in cases in which the courts have justified the admission of rebuttal evidence to correct a "mis-painted picture" gratuitously drawn by a witness. ${ }^{168}$ Because the collateral-matter rule is a judge-made rule created largely to assist juries by expediting trials and minimizing confusion, judges have the discretion to withhold the rule when its operation would foster rather than dispel confusion.

But a continued and careful balancing is necessary. Often the rebuttal evidence may overcompensate for the imbalance sought to be offset. Other-crimes evidence may be too potent. To allow rebuttal of testimony elicited on cross-examination is likely to open a hole in the carefully constructed barrier against the use of misconduct evidence to show propensity. ${ }^{169}$ Thus, even where courts have einbraced the sweeping-claims exception, the inore perceptive of them have recognized that it is subject to the over-arching considerations of rule 403.170 Courts need not allow every erroneous statement on a collateral point to be corrected with extrinsic counterproof. But sone points should be, particularly when it is fairly evident that the witness has deliberately hed about a matter in which he or she could not be mistaken, and the fabrication, if left uncorrected, might seriously mislead the jury. Certainly the jury, upon hearing a criminal defendant volunteer, for example, that he has never been in trouble before, expects contradiction of that fact if it is not true. And if no rebuttal is heard, it is reasonable, if

any such conversation took place [on direct], he cannot now complain that testimony reflecting upon his truthfulness was admitted on rebuttal").

168. See United States v. Batts (Batts II), 573 F.2d 599, 603 (9th Cir.), cert. denied, 439 U.S. 859 (1978); United States v. Salvitti, 451 F. Supp. 195, 203 (E.D. Pa.), afjd, 588 F.2d 824 (3rd Cir. 1978) (the defendant's direct testimony "plainly sought to convey to the jury . . . that the defendant was an.honorable public servant who had never received a bribe").

169. See United States v. Pantone, 609 F.2d 675, 681 (3rd Cir. 1979); FED. R. Evid. 404(b).

170. See, eg., United States v. Green, 648 F.2d 587, 595 (9th Cir: 1981); United States v. Pantone, 609 F.2d 675, 681 (3d Cir. 1979); United States v. Benedetto, 571 F.2d 1246, 1250 n.7 (2d Cir. 1978). 
not inevitable, for the jury to conclude that this is the defendant's first scrape with the law. Few would deny that such a conclusion, rightly or wrongly, would influence their decision. ${ }^{171}$

\section{The Sweeping-Claims Exception After United States v. Havens.}

The injection of extrinsic rebuttal into the trial as an antidote for perjury is not justified by the presence of perjury alone. How the perjury got into the trial is important. Because the presentation of contradicting proof may itself have serious destabilizing side-effects on the trial, the rebuttal nust be avoided until the witness who caused the problein in the first place has hiterally asked for it. Permitting the crossexaminer to maneuver the witness into testifying falsely about embarrassing collateral matters is tantamount to allowing the cross-examiner to administer the antidote whenever he desires. ${ }^{172}$ Hence, the courts insist that sweeping claims be volunteered on direct or cross-examination before the exception is permitted to operate. It is in this context that the recent Supreme Court decision in United States v. Havens ${ }^{173}$ inust be scrutinized. There is a danger that courts may read Havens as eliminating the dichotomy between inatters elicited on direct and those elicited on cross-examination by failing to focus upon the distinction between collateral and noncollateral inatters. Havens should not disturb this direct-cross distinction when extrinsic evidence is offered to rebut false testimony on a collateral issue.

Havens was arrested after arriving at the Miami, Florida, airport from Peru. Shortly before Havens's arrest, airport customs agents discovered a man named McLeroth, who also arrived from Peru and was carrying cocame in inakeshift pockets sewn into his T-shirt. McLeroth implicated Havens in the smuggling scheine. Federal narcotics agents

171. The author of this article has presented criminal cases to many grand juries. During or after presentation of the occurrence witnesses, the one question invariably asked by the jurors was, "Has he ever been in trouble before?" For the same reasons which underhie Federal Rule 404(b), the question would always go unanswered, but the natural desire on the part of the jury to obtain this information is understandable.

172. See authorities cited in note 169 supra. To use an overly simplistic example, assume a defendant accused of theft denies the crime on the stand. If the prosecutor is allowed to ask on cross-examination, based on good faith information, whether the defendant tortures stray cats as a hobby, it is very likely that, even if true, the defendant will deny it. If he admits it, he may harm himself in the eyes of the jury. If he denies it, he will be lying, but about something totally foreign to the case being tried. Faced with this dilemma, it is more likely that the defendant will avoid certain ignominy and deny the allegation, hoping that the prosecutor is bluffing and has no evidence awaiting. If the prosecutor is permitted to contradict this falsehood, then every inadmissible and prejudicial fact about a witness capable of being proved could be injected into a trial at the whim and caprice of the prosecutor.

173. 446 U.S. 620 (1980). 
arrested Havens and searched his luggage without a warrant. There they found a medium sized T-shirt from which pieces were cut that corresponded to the patches sewn onto McLeroth's shirt to make pockets. McLeroth pleaded guilty to one of three counts in the indictment and agreed to testify agamst Havens. Prior to trial, the court suppressed the T-shirt found in Havens's luggage. ${ }^{174}$

At trial, McLeroth testified that he, Havens, and others were involved in a cocaine sinuggling scheine. ${ }^{175} \mathrm{He}$ described the first trip, claiming that Havens had taped bags of cocaine to McLeroth's body. ${ }^{176}$ On the trip that ended with their arrests, McLeroth claimed, Havens had supplied him with the altered T-shirt and had sewn the bags of cocaine into the pockets. ${ }^{177}$

Havens derined knowledge of McLeroth's smuggling activities, and his direct testimony continued as follows:

Q. And you heard Mr. McLeroth testify earlier as to something to the effect that this material was taped or draped around his body and so on, you heard that testimony?

A. Yes, I did.

Q. Did you ever engage in that kind of activity with Mr. McLeroth and Augusto or Mr. McLeroth and anyone else on that fourth visit to Lima, Peru?

\section{A. I did not. ${ }^{178}$}

On cross-examination, the prosecutor asked Havens if his testimony was that he "had nothing to do with the sewing of the cotton swatches to make pockets on that tee shirt." 179 When Havens agreed, the prosecutor asked him whether, when he came through custorns, he had in his luggage any T-shirts smaller than those lie normally wore. This question prompted a defense objection that the impeachunent was improper because the inatter of the T-shirt was not inentioned on direct. The judge responded, "It does not have to be covered on direct. If he denies something under oath, which is-.".180 The prosecutor then confronted Havens with the illegally seized T-shirt and asked if it had been in his suitcase when he was arrested. Havens replied, "Not to iny knowledge. No."181 On rebuttal, the prosecutor called an agent who

174. Id. at 621-22.

175. United States v. Havens, 592 F.2d 848, 850 (5th Cir. 1979), rev'd, 446 U.S. 620 (1980).

176. Brief for Petitioner at 4 n.2, United States v. Havens, 446 U.S. 620 (1980).

177. Brief for Petitioner at 4 .

178. 592 F.2d at 850 .

179. 446 U.S. at 622-23.

180. 592 F.2d at 852 .

18i. 446 U.S. at 623. 
described how he found the T-shirt in the defendant's luggage and testified that Havens had stated that the shirt belonged to McLeroth. Over objection, the T-shirt was admitted into evidence for the purpose of impeaching the defendant. ${ }^{182}$

The Court of Appeals for the Fifth Circuit, after reviewing the Agnello-Walder-Harris line of cases and two cases from other circuits, ${ }^{183}$ rejected the trial court's view that any demal, either on direct or on cross-examination, opens the door to rebuttal with tainted evidence. ${ }^{184}$ The court examined Havens's direct testimony to determine whether the rebuttal evidence contradicted anything said there, and noted that the defendant's counsel "did not ask Havens anything at all about a T-shirt, nor was he asked about the contents of his luggage." 185 Therefore, because the impeaching evidence was predicated on Havens's cross-examination testimony, the trial court erred under Agnello and Walder.

The Supreme Court agreed that the government's rebuttal evidence did not "squarely contradict the defendant's testimony on direct examination." 186 Nevertheless, it reversed. In a 5-4 decision, ${ }^{187}$ Justice White reduced the holdings of Agnello, Walder, and Harris to a single proposition: "[W]hen defendants testify, they must testify truthfully or suffer the consequences," 188 regardless of whether their testimony is on direct or cross-examination. The constitutional exclusionary rule does not impede the impeachinent process. ${ }^{189}$

Although Agnello represented a inajor obstacle to reversal, the Court did not explicitly overrule it. The majority opinion finessed Agnello by redefining the concept of "smuggling in" the opportunity to impeach during cross-examination. Justice White pointed to the language in Agnello noting that Agnello had said nothing on direct exainination to justify cross-examination regarding the illegally seized

182. $I d$.

183. United States v. Mariani, 539 F.2d 915 (2d Cir. 1976); United States v. Trejo, 501 F.2d 138 (9th Cir. 1974).

184. $592 \mathrm{~F} .2 \mathrm{~d}$ at 851 . See text accompanying note 180 supra.

185. 592 F.2d at 852 .

186. 446 U.S. at 621 . The Court stated that the single issue presented by the Hovens appeal was "whether evidence suppressed as the fruit of an unlawful search and seizure may nevertheless be used to impeach a defendant's false trial testimony, given in response to proper cross-examination, where the evidence does not squarely contradict the defendant's testimony on direct examination." Id.

187. Justices Brennan, Stewart, Marshall, and Stevens dissented, agreeing that the decision did not correctly follow precedent. Justices Brennan and Marshall went on to condemn the erosion of the exclusionary rule. See id. at 629.

188. 446 U.S. at 626.

189. Id. at 627 . 
evidence. 190 Justice White then redefined the Walder definition of Agnello, and stated that $A$ gnello was merely a case in which the "crossexamination [had] too tenuous a connection with any subject opened upon direct examination to permit impeachment by tainted evidence." 191 Therefore if the questions on cross-examination, the answers to which contradict reliable, though tamted, evidence, "would have been suggested to a reasonably competent cross-examiner by Havens's direct testimony, they were not 'smuggled im." "192 The contradictimg evidence did not involve a collateral matter; the Court held that Havens's denial on direct that he had "ever engage[d] in that kind of activity with Mr. McLeroth," 193 was tantamount to a denial of his having anything to do with altering McLeroth's T-shirt. Therefore, Havens's direct testimony reasonably suggested cross-examination about the T-shirt McLeroth was wearing, and about the cut-up counterpart found in Havens's suitcase. ${ }^{194}$

Havens is more similar to Harris than it is to Walder from the poimt of view of collateral and noncollateral impeachment. In Harris, as in Havens, the impeaching evidence was directly probative of the defendant's guilt, and would have been allowed in on the merits during the government's case-in-chief but for its unconstitutional taint. In Walder, however, the tainted rebuttal evidence was madmissible during the government's case-in-chief for evidentiary reasons as well as for constitutional reasons. Walder's unrelated drug possession charge two years before his trial was inadmissible under the rule that forbids evidence of prior specific acts to prove the propensity to commit similar acts. ${ }^{195}$ Walder's general denial on direct examination of ever having possessed drugs swept away both the constitutional and evidentiary barriers to the admission of the evidence, at least for impeachment purposes. The Supreme Court found Havens's cross-examination denial sufficient to overcome the constitutional barrier to the admission of the tamted evidence. If the contradiction is noncollateral, it makes no difference whether the testimony contradicted is elicited on direct or on cross-examination. Therefore, the Supreme Court's holding in Havens

190. Id at 625. The reference is to the following language in Agnello v. United States, 269 U.S. 20, 35 (1925): "In his direct examination, Agnello was not asked and did not testify concerning the [illegally seized] can of cocaine. . . . He did nothing to waive his constitutional protection or to justify cross-examination in respect of the evidence claimed to have been obtained by the search."

191. 446 U.S. at 625.

192. Id.

193. Id. at 628 .

194. Id

195. See FED. R. Evid. 404(b); C. McCoRMICK, supra note 2, § 42. 
that "a defendant's statements made in response to proper cross-examination reasonably suggested by the defendant's direct examination are subject to otherwise proper impeachment . . . albeit by evidence that has been illegally obtained," 196 is consistent with evidence law. Absent the constitutional exclusionary rule, the impeachment was "otherwise proper," notwithstanding the lack of a sweeping claim during direct testimony.

But Havens should not be read to eliminate the need for a sweeping claim on direct examination when the rebuttal evidence concerns a collateral matter. Although the Court removed the constitutional barrier to the admission of such evidence, it did not lift the ban on collateral impeachment with extrinsic proof, 197 for it stated that the impeachment must be "otherwise proper." 198 As the substantial weight of federal case law now holds, there must be a sweeping claim on direct before extrinsic impeachment on a collateral matter is permitted. Havens does not disturb this doctrine, for the matter rebutted in that case was noncollateral. Therefore, from an evidentiary point of view, Agnello still has vitahty. The Supreme Court reads Agnello as involving extrinsic impeachment on a collateral matter raised first on crossexamination. ${ }^{199}$ In such instances, the impeachment of Agnello apart from the constitutional exclusion was not "otherwise proper." It amounted to collateral impeachment with extrinsic evidence absent a sweeping claim to justify the contradiction.

The following diagram illustrates how the major cases can be viewed from the perspective of extrinsic contradiction:

196. 446 U.S. at $627-28$ (emphasis added).

197. The Court stated:

[W]e do not understand the District Court to have indicated that the Government's question, the answer to which is sought to be impeached, need not be proper cross-examination in the first instance. The Court of Appeals did not suggest that either the crossexamination or the impeachment of Havens would have been improper absent the use of illegally seized evidence, and we cannot accept respondent's suggestions that because of the illegal search and seizure, the Government's questions about the T-shirt were improper cross-examination.

Id. at 628.

198. Id. at 627.

199. The Court stated in Havens: "The implication of Walder is that Agnello was a case of cross-examination having too tenuous a connection with any subject opened upon direct exammation to permit impeachment by tainted evidence." Id. at 625 . 
The Matter First Raised on

\section{Direct}

Cross

The Matter Is

Collateral

Noncollateral
Contradiction Permitted (Walder)

Contradiction Permitted (Harris)
Contradiction Not Permitted (Agnello)

Contradiction Permitted

(Havens)

This way of viewing the cases demonstrates why Agnello survives Havens. Otherwise the exception will have swallowed the rule. Indeed, if the collateral-matter rule has any meaning after Havens, Agnello must stand for the proposition that a prosecutor may not introduce extrinsic rebuttal evidence, tainted or untainted, elicited for the first time on cross-examination to contradict the testimony of a defendant on a collateral matter.

The Supreme Court in Walder correctly stated, as a matter of evidence law, that the impeaching evidence was admissible only to undermine the defendant's credibility. ${ }^{200}$ This conclusion follows because the impeaching evidence of prior criminal conduct was unrelated to the trial charges. Such evidence has only one other possible use and this use is impermissible. Unless the evidence is restricted to the question of his credibility as a witness, evidence of unrelated crimes may be used by the jury as proof of the defendant's bad character, that is, his disposition or propensity to commit crime. And if they conclude that he has such a propensity, they may convict him although the other evidence of guilt is insufficient to prove guilt beyond a reasonable doubt. ${ }^{201}$ Consequently, the courts are on firm ground in limiting tainted other-crimes evidence to impeaching credibility when the evidence is collateral to the issues at trial.

Noncollateral contradicting evidence, like that in Harris and Havens, is offered to contradict the testimony of a witness on a material point. The evidence is admitted both to impeach by specific error, and to disprove substantively the point made by the previous witness. ${ }^{202}$ If the defendant opens the door, and thus removes the exclusionary rule's barrier, the evidence shonld come in for whatever purposes the rules of evidence permit. For example, in Havens the rebuttal evidence directly connected the defendant to the crime. Once the constitutional exclusion of the tamted evidence was lifted as a result of Havens's testimony, the evidence should have been treated in the same manner as any other

200. Walder v. United States, 347 U.S. 62,65 (1954).

201. See C. McCormick, supra note 2, § 190.

202. See 3 D. LouISELl \& C. MUELLER, supra note $71, \S 343$. 
evidence that contradicts the testimony of a witness on a material point, namely, to prove or to disprove that material fact, as well as to impeach the witness's credibility by specific contradiction. ${ }^{203}$

In other words, the sweeping-claims exception is a rule of evidence, not merely a waiver of the protections of the constitutional exclusionary rule. And as a rule of evidence, it should operate to its fullest extent. It begs the question to argue that constitutionally tainted, noncollateral evidence should not be used for substantive purposes even after the defendant voluntarily opens the door. The Supreme Court has stated that the sweeping admonition of Silverthorne Lumber Co. v. United States ${ }^{204}$-that illegally seized evidence cannot be used at all - has been limited. ${ }^{205}$ Silverthorne's prohibition has been modified to mean that tainted evidence can never be used on the nierits, but this distinction is artificial im that it has not been adequately explained. Once the prosecutor is allowed to "toss the skunk into the jury box," it is fantasy to expect the jury not to sinell it. But more importantly, the Supreme Court currently evaluates every ramification of the exclusionary rule to determine its deterrent effect. If the exclusion of evidence from a certam portion of the trial does not appreciably advance the goal of deterring illegal police behavior, then courts trim away that aspect of the rule. ${ }^{206}$ Elimination of the impeachment-only restriction on the use of illegal evidence directly relevant to the defendant's guilt hardly will spawn an increase im constitutional abuses by the police. The prosecutor will continue to be prohibited from introducing the evidence until the defendant causes the exclusionary rule to be lifted. Elimination of the impeachment-only restriction will not diminish the principal deterrent effect of the rule, which arises from the exclusion of evidence from the prosecutor's case-in-chief.

\section{RECOMMENDATIONS}

The introduction of extrinsic testimony to contradict an adverse witness's sworn testimony can be a critical event in a trial. It can change a jury's entire outlook on a witness's testimony and, ultimately, the merits of the case presented by the party who originally called the

203. United States v. Havens, 446 U.S. $620,624-28$ (1980).

204. 251 U.S. 385,392 (1920).

205. E.g.; United States v. Calandra, 414 U.S. 338 (1974). See Pitler, "The Fruit of the Poisonous Tree" Revisited and Shepardized, 56 CALIF. L. REv. 579 (1968).

206. See Michigan v. DeFillippo, 443 U.S. 31 (1979) (exclusionary rule doos not rcquire suppression of evidence seized incident to a valid arrest under an ordinance later declared unconstitutional); Unitcd States v. Calandra, 414 U.S. 338 (1974) (witness summoned to testify before grand jury may not refuse to answer questions based on evidence obtained froin an unlawful search). See also United States v. Janis, 428 U.S. 433 (1976); Stone v. Powell, 428 U.S. 465 (1976). 
witness. When the point of testimony on which the witness is to be specifically contradicted is collateral, the Hitchcock rule recognizes that the dangers of confusion of issues, surprise, and wasting time arise. And when the contradicting evidence reveals prior misconduct of the witness, the law recognizes the danger that the jury may misuse the evidence. 207

Since the Walder decision, the courts have embraced an exception to the prohibition on extrinsic impeachment on collateral matters. The courts will ignore or endure problems of time, confusion, and surprise when the sweeping collateral testimony is apparently false, advantageous to the witness or his proponent, and mitially raised during his direct examination. Indeed, trial courts have permitted collateral contradiction even when it brings to the trial the additional prejudice inherent in other-crimes evidence. Courts of appeals have ceased reversing cases in which the trial judge permits this kind of erosion of the collateral-inatter rule; instead they rule that trial judges have the discretion to admit this impeaching evidence. ${ }^{208}$

This erosion of the collateral-matter rule reflects a more permissive attitude among modern jurists toward what the jury should hear. Certainly, a flat prohibition of all extrinsic impeachinent testimony not strictly inaterial to the disputed issues, although avoiding the aforementioned dangers, can deprive the factinders of valuable information. ${ }^{209}$ Appellate judges no doubt realize this consequence, and recognize that the trial judge is in the best position to balance the likely costs against the possible gains resulting from the admission of certain evidence. ${ }^{210}$

Added to these considerations are the unique features of a criminal trial. Judges permit collateral impeachinent more frequently in criminal prosecutions than in civil trials. Perhaps the issue simply arises more often in criminal trials. The higher stakes of a criminal trial一social and moral stigma and the possible loss of liberty-nay coinpel witnesses to overstate testimony and succumb to the temptation to make a sweeping claim or denial. However, this does not account for the increased permissiveness of the courts toward collateral impeachinent of criminal defendants. The criminal defendant is uniquely prejudiced by the introduction of his uncharged prior criminal conduct to rebut his general claim of probity. It seems the equities favor exclusion. The explanation for the courts' increased willingness to allow ad-

207. See FED. R. Evid. 404(b), 608(b); C. MCCoRMICK, supra note 2, § 190.

208. See notes 223-24 infra.

209. See generally J. WIGMORE, supra note 2, § 1002.

210. See note 222 infra. 
mission of such evidence probably lies in a subtly changed view of the criminal justice system. ${ }^{211}$ In balancing the competing interests of allowing the jury to hear more facts and of protecting the accused from police misconduct in obtaining those facts, courts now place more weight on the "integrity of the factfinding goals of the criminal trial."212

There is good reason to view this development as an improvement in the administration of justice in our courts. Wigmore's statement of the collateral-matter test ${ }^{213}$ is too rigid. Courts have had to ignore or bend the rule to permit extrinsic contradiction of linchpin facts or to avoid excluding potentially crucial impeachment evidence. To avoid mjustice, they have stretched the doctrines of curative admissibility and mipeaching character "placed in issue" beyond recognizable limits. The use of Wigmore's formulation of the rule has thus forced the courts to break other evidentiary rules.

By adopting the sweeping-claim-on-direct exception, an impressive majority of state courts ${ }^{214}$ have demonstrated the importance of the exception to the truth-seeking function of trials. The laudable policies reflected in the collateral-matter rule should be subordinated to that function when a gratuitous sweeping claim can be quickly unmasked as false. When the prosecutor elicits the falsehood during cross-examination, however, the courts still adhere to the collateralmatter rule. The defendant may not use the constitutional exclusionary rule or the collateral-matter rule to perjure with impunity, but the prosecutor may not evade these same rules simply by asking questions that touch on madmissible evidence. The sweeping-claims exception is necessary to curb testmionial abuses by witnesses, but Agnello and the collateral-matter rule are necessary to curb prosecutorial abuses.

211. See Bradley, Havens, Jenkins, and Salvucci, and the Defendant's "Right" to Testify, 18 AM. CRIM. L. Rev. 419 (1981). See note 206 supra.

212. United States v. Havens, 446 U.S. 620,627 (1980).

213. See notes 14-17 supra and acconipanying text.

214. The author has found only one out of the twenty-one states cited in note 1 supra that has flatly rejected the sweeping-claims exception. In McClelland v. State, 84 Wis. 2d 145, 267 N.W.2d 843 (1978), the defendant testified on direct examination that he had not been involved in any criminal activity since 1972. The Wisconsin Supreme Court held that the trial judge erred in allowing the prosecutor to rebut the sweeping statenent with evidence that the defendant had been involved in an armed burglary five days after the robbery for which he was on trial. The majority held that the collateral-inatter rule prohibited the impeachment. Id. at 160-62, 267 N.W.2d at 850-51. The dissent, citing Walder and Harris, argued that the defendant opened the door to impeachment with his sweeping denial on direct. Id. at 163-65, 267 N.W.2d at 851-52. See also State v. Spraggins, 71 Wis. 2d 604, 239 N.W.2d 297 (1976).

The North Dakota Supreine Court, in dicta, rejected the exception in State v. Larson, 253 N.W.2d 433, 436 (N.D. 1977), but Larson focused on the false statement niade by a witness on cross-examination. 
The Federal Rules of Evidence attempt to eliminate false and misleading testimony without creating a process that is unfair and unduly time-consuming. Rule 102 explains: "These rules shall be construed to secure fairness in administration, elimination of unjustifiable expense and delay, and promotion of growth and development of the law of evidence to the end that the truth may be ascertained and proceedings justly determined."215 A careful consideration of this language leads one to conclude that the sweeping-claims exception is consistent with its inessage, and that the courts should not use Havens to undermine Agnello and the collateral-matter rule. But the hortatory language of rule 102 is insufficient guidance for the trial courts in the areas of extrinsic impeachment by contradiction, the collateral-matter rule, and the sweeping-claims exception. Because the Federal Rules of Evidence do not speak expressly of these doctrines, the courts inust navigate in relatively uncharted seas. Only rule 608(b) purports to guide them in their rulings on collateral impeachment with extrinsic evidence of prior misconduct, and rule 608(b) is a misleading guidepost. Thus, the state and federal courts that implement the rules are in disarray. The rules should be amended to provide more guidance to these courts.

\section{A. A Proposed Amendment to Federal Rule 607.}

The Federal Rules of Evidence should codify the doctrine that certain attacks on credibility are not collateral and may be conducted with extrinsic testimony. Evidence demonstrating the bias of a witness inay be the prime example, 216 but the rules should also specifically permit other noncollateral modes of attack on the credibility of a witness. In drafting a list of the perumssible methods of impeaching the credibility

\footnotetext{
215. FED. R. Evid. 102.
}

216. See, e.g., United States v. James, 609 F.2d 36 (2d Cir. 1979) (the pendency of a criminal prosecution against prosecution witness), cert. denied, 445 U.S. 905 (1980); United States v. Harvey, 547 F.2d 720 (2d Cir. 1976) (government witness had accused defendant of fathering her illegitimate child and had vowed revenge); United States v. Kelley, 545 F.2d 619 (8th Cir. 1976) (government witnesses nade threats against defendants), cert. denied, 430 U.S. 933 (1977); Johnson v. Brewer, 521 F.2d 556 (8th Cir. 1975) (prosecution's witness-informer had "framed" a previous defendant in a similar case); United States v. Kinnard, 465 F.2d 566 (D.C. Cir. 1972) (government informer-witness was a drug addict while working as a police operative); United States v. Haggett, 438 F.2d 396 (2d Cir.) (the prosecution witness had stated that he was "out to get" defendant), cert. denied, 402 U.S. 946 (1971); Goodwin v. State, 263 Ark. 856, 568 S.w.2d 3 (1978) (prosecution witness threatened to retaliate if defendant did not become an informer); State v. Jones, 25 Wash. App. 746, 610 P.2d 931 (1980) (government witness threatened to "fry" the defendant with his testimony). Cf. United States v. Moore, 529 F.2d 355 (D.C. Cir. 1976) (failnre of defense counsel to introduce evidence that prosecution witness was having an affair with defendant's wife because counsel nay have believed it to be a "collateral" issue); Reichenbach v. Smith, 528 F.2d 1072 (5th Cir. 1976) (refusal to allow one of the losing defendants to introduce evidence of a secret argument between the plamtiff and a codefendant was not prejndicial error). 
of witnesses, proponents of such an amendment should use as models the California Evidence Code, ${ }^{217}$ Florida's adaptation of the Federal Rules of Evidence, ${ }^{218}$ and the proposed Texas evidence code. ${ }^{219}$ Like the California code and the proposed Texas code, the listmg need not be exclusive. A witness may be impeached in innumerable ways; any

\section{CAL. Evid. CoDe $\S 780$ (West 1966) states:}

General rule as to credibility. Except as otherwise provided by statute, the court or jury may consider in determining the credibility of a witness any matter that has any tendency in reason to prove or disprove the truthfulness of his testimony at the hearing, including but not limited to any of the following:

(a) His demeanor while testifying . . . .

(b) The character of his testimony.

(c) The extent of his capacity to perceive, to recollect, or to communicate any matter about which he testifies.

(d) The extent of his opportunity to perceive ....

(e) His character for honesty or veracity or their opposites.

(f) The existence or nonexistence of a bias, interest, or other motive.

(g) A statement previously made by him that is consistent with his testimony at the hearing.

(h) A statement made by him that is inconsistent with any part of his testimony at the hearing.

(i) The existence or nonexistence of any fact testified to by him.

(j) His attitude toward the action in which he testifies or toward the giving of testimony.

(k) His admissions of untruthfulness.

218. FLA. STAT. ANN. $\S 90.608$ (West 1979) provides in relevant part:

Who may impeach

(1) Any party, except the party calling the witness, may attack the credibility of a witness by:

(a) Introducing statements of the witness which are inconsistent with lis present testimony.

(h) Showing that the witness is biased.

(c) Attacking the claracter of the witness in accordance with the provisions of $\S 90.609$ or $\$ 90.610$.

(d) Showing a defect of capacity, ability or opportunity in the witness to observe, remember, or recount the inatters about which he testified.

(e) Proof by other witnesses that material facts are not as testified to by the vitness being impeached.

219. The proposed Texas rule reads:

\section{Rule 607 \\ IMPEACHMENT GENERALLY}

(a) The credibility of a witness unay be attacked by the opposing party by proof of bias, interest, inconsistent statements, traits of cliaracter affecting credibility, any impairment or disability affecting crcdibility, or by any other circumstances which the trial court beheves would reasonably affect the credibility of the witness.

(h) A witness may also be impeached by the opposing party by cross-examination or extrinsic evidence contradicting the witness' testimony on matters directly in issue or matters affecting the witness' credibility, as provided in these rules, but a witness may not be impeached by contradiction on collateral matters unless in the opmion of the trial judge the impeachment evidence gives promise of exposing falseliood or should be admittcd in the interests of justice.

(c) The credibility of a witness may not be attacked by the party placing him on the stand or by a party with like interests without a showing that such witness' testimony is injurious to said party's cause and that the nature of the witness' testimony surprised said party, and in no event may such party offer evidence of such witness' bad character.

Black, The Texas Rules of Evidence-A Proposed Codification, 31 Sw. L.J. 969, 985 (1977). 
attempt to state all methods of impeachment is bound to fail. ${ }^{220}$

Drafters of the amendment must try to avoid the danger that the codified collateral-matter rule may be enforced too strictly. ${ }^{221}$ Most treatise writers recommend that trial courts be given more flexibility in admitting or excluding extrinsic evidence that impeaches a witness on a strictly collateral point. ${ }^{222}$ This result would, in effect, validate the way in which many courts presently handle extrinsic contradiction when it runs afoul of the collateral-matter rule. ${ }^{223}$ Leaving the matter in the

220. The Florida code apparently attempts an exhaustive list, see note 218 supra, yet it omits the form of impeachment involving proof of lack of qualifications or skills of an expert witness. See J. WIGMORE, supra note 2, §§ 991, 1005.

221. The Califorma Law Revision Committee voiced this concern when it considered adopting the Uniform Rules of Evidence which, in effect, eliminate the strict prohibition on collateral impeachment in favor of a rule of discretiou. See 6 CAL. LAw Revision CoMm'N, A STUDY RELATING to THE WitNesses, in RePorTs, Recommendations AND STUDIES 725, 750 (1964). As a result, section 780(i) of the Califorma Code, see note 217, states that the existence or nonexistence of "any" fact, as opposed to a "material" fact, may be shown to discredit a witness. Compare Fla. STAT. ANN. $\S 90.608$ (e) (West 1979) (reproduced in note 218 supra).

222. See 2 D. Louisell \& C. MUELleR, supra note 71 , § 129; 3 J. WeinsteIn \& M. BERGER, supra note 153, I 607[05]; J. WIGMORE, supra note 2, §§ 1003, 1005. The comment to rule 106 of the American Law Institute's Model Code of Evidence observes:

The balance which should be struck between the value of any itein of evidence affecting credibility and these risks [unfair surprise, undue consumption of time, confusion of issues, and illegitimate prejudice] as they appear at a trial is to be determined by the exercise of a sound judgmeut, and the judge' is in an especially favorable position to excrcise it. He should not be bound by rules of thumb... .

MODEl CODE of EvidenCE rule 106, Comments, at 119 (1942).

223. "The cases dealing with discretion in the field of contradiction seem to go further than [this] text. Some imply that the trial judge las discretion to decide what is and is not collateral .... Others suggest that even if collateral the judge has a discretion to permit the contradiction." C. MCCoRMICK, supra note 2, § 47, at 100 n.58; e.g., United States v. Pantone, 609 F.2d 675, 682 (3d Cir. 1979) ("The doctrine of Walder . . . , as preserved in [Federal Rule of Evidence] 607 , gives a trial judge discretion to admit otherwise inadmissible extrinsic evidence tendmg to contradict any specific testimony volunteered to by a witness on direct exammation"); Umitcd States v. Batts (Batts II), 573 F.2d 599, 603 (9th Cir.) ("It inust also be remembered that the admissibility of rebuttal evidence is subject to the sound discretion of the trial court"), cert. denied, 439 U.S. 859 (1978). United States v. Benedetto, 571 F.2d 1246, 1250 (2d Cir. 1978) ("Once a witness (especially a defendant-witness) testifies as to any specific fact on direct testimony, the trial judge lias broad discretion to admit extrinsic evidence tending to contradict the specific statement, even if sucl statement concerns a collateral matter in the case"); Umited States v. Alvarez-Lopez, 559 F.2d 1155, 1158 (9th Cir. 1977) ("[I]mpeachment upon collateral matters inay be particularly subject to potential abuse, and in those situations, [the federal rules] . . give substantial discretion to the trial court in admitting or excluding the impeaching evidence"); State v. Davis, 117 Ariz. 5, 7, 570 P.2d 776, 778 (Ariz. App. 1977) ("The admission or exclusion of testimony as to immaterial or collateral materials for the purpose of impeachment is left to the sound discretion of the trial court"); State v. McCrillis, 376 A.2d 95, 98 (Me. 1977) ("It is well-settled that the presiding Justice has discretiou to exclude evidence calculated to impeach, or contradict, testimony first elicited . . . during cross-examinatiou as to matters which are collateral . . ."); Allen v. State, 94 Nev. 285, 286, 579 P.2d 771, 772 (1978) ("Although appellant was impeached as to collateral matters, we believe " $[$ ] $]$ he impeachment process here undoubtedly provided valuable aid to the jury in assessing [appellant's] credibility. . . . Tlus, the evidence was more probative than prejudicial and, therefore, was properly admitted" (citations omitted)). 
hands of the trial judge makes sense, for he is in the best position to weigh the competing interests. ${ }^{224}$ The trial judge can best determme if the testimony to be impeached is a deliberate falsehood injected into the trial by the witness to gain an unfair advantage over his opponent, or whether it is the result of a good faith error or mistake.

The trial judge is also in the best position to demand an offer of proof from the party seeking to mipeach ${ }^{225}$ and he can thereby determine whether the proffered evidence squarely contradicts prior testimony, or only tangentially casts doubt on it; whether the contradiction will be quick and efficient, or will entail the testimony of many witnesses; whether the contradiction will engender a spate of witnesses called to rebut the rebuttal; and, most importantly, whether the credibility of the witness to be impeached is the keystone of one party's case, and the extent to which the fact finder would be left with a false picture of the crucial witness's credibility without hearimg the contradiction. Furthermore, if a prosecutor seeks to contradict a criminal defendant with evidence of his prior criminal acts not resultimg in a conviction, the trial court can best assess the added prejudice, and the circumstances under which the matter was originally introduced. Therefore, the rule must be drafted to make the considerations of rule 403 paramount to a mere determination of whether the impeaching evidence goes to a collateral or a noncollateral fact.

Because rule 607 initiates the topic of impeachinent of witnesses in Article VI, 226 it is logical to list the permitted forms of imipeachinent in an amendment to that rule. The following proposal meets the need for an exphicit statement of the collateral-matter rule in the Federal Rules of Evidence:

\section{Rule 607 \\ Impeachment}

(a) Generally. The credibility of a witness may be attacked by any party, including the party calling him, 227 either on cross-examination or by extrinsic testimony, by proof

(1) of bias, interest, or other motive; 228

224. See MODEL CODE OF EvideNCE rule 106, Comments (1942), supra note 222. "[Some] courts are content to invoke simply the term collateral and to decide according to the circumstances of each case. The sound rule would be to leave the application of the rule largely in the control of the trial court; and this is the flexible practice in some jurisdictions today." J. WIoMORE, supra note $2, \S 1003$, at $962-64$ (footnote omitted).

225. See Fed. R. Evid. 103, 104.

226. See text accompanying notes 151-53 supra.

227. This wording is presently used in rule 607 .

228. This language is taken froin CAL. Evid. CODE $\$ 780(1)$ (West 1966). The text of this section is set out in note 217 supra. 
(2) of an inability of the witness to observe, reinember, or recount the matter about which he testified;229

(3) in accordance with Rule 613, that prior statements of the witness being impeached concerning material facts are inconsistent with the witness's present testimony; ${ }^{230}$

(4) of traits of character as provided by Rules 608 and 609;231

(5) that inaterial facts are not as testified to by the witness being impeached; 232

(6) of any other circumstance that, after due consideration of the provisions of Rule 403, the court determines would reasonably affect the credibility of the witness. ${ }^{233}$

(b) Extrinsic impeachment of immaterial facts. A witness's testimony regarding immaterial facts may not be contradicted with extrinsic evidence unless the court determines that

(1) the probative value of the impeaching evidence outweighs the dangers histed in Rule 403; and

229. This portion of the proposed rule is a modified version of FLA. STAT. ANN. $\$ 90.608$ (d) (West 1979). The text of this section is reproduced in note 218 supra. The Florida statute speaks in terms of "a defect of capacity in the witness." It was intended, no doubt, that the term "defect of capacity" cover both a lack of opportunity to observe, implying an inability to observe resulting from external causes, as well as a lack of capacity to observe, which connotes a subjective cause of the perception problem. The term "inability" better conveys the dual possibilities that both objective and subjective factors can limit perception.

230. Accord FlA. STAT. ANN. $\$ 90.608$ (a) (West 1979). This formulation is essentially the same except that a reference to rule 613 was thought appropriate because that rule mandates a certain foundation before extrinsic proof may be offered. The addition of the word "material" to the proposed clause further limits impeachment by imconsistent statements. This addition recognizes that the collateral-matter rule applies to impeachment by contradiction with prior inconsistent statements. Thus, extrinsic proof is limited to statements concerning material facts. See J. WIGMORE, supra note $2, \S 1019$.

231. Once a witness, as the courts misleadingly phrase it, has "put his character in issue," the credibility of the witness may be attacked by proof that he has an untruthful character. FED. R. Evib. 404(a)(3), 608(a); C. MCCoRiMICK, supra note 2, § 41. The proposed rule 607(a)(4) states this proposition and refers the reader to rules 608 and 609 , which govern this type of impeachment.

232. This provision is substantially the same as FLA. StaT. ANN. $\$ 90.608(e)$ (West 1979), except that the words "proof by other witnesses" are omitted. Florida's inclusion of these words only in subsection (e), and not in any of the other four provisions governing how a witness may be impeached can be misinterpreted to mean that extrinsic evidence is permitted ouly to contradict a witness on material, noncollateral facts, and not to show, under subsection (a), that a witness is biased, or under subsection (d), that he liad a defect in his capacity to observe. To avoid this possible confusion, the proposed rule 607(a) states that extrinsic evidence may be offered to prove all of the matters listed in this subsection. See J. W1GMORE, supra note 2, § 1005.

233. This catch-all provision, like section 780 of the California Code, see note 217 supra, and the proposed Texas version of rule 607, see note 219 supra, from which the language is taken, recognizes that it is unwise to attempt to write an exclusive list of impeaching methods. The proposed rule specifically adds that any other method of attacking credibility, such as by proof of prior failures to exercise skill on the part of an expert witness, see J. W1GMORE, supra note 2, $\$ \$ 991,1005$, or by drawing attention to the witness's demeanor or to the character of his testimony, see CAL. Evid. CODE $\$ 780$ (a)-(b) (West 1966), is permitted ouly after the trial judge has determined that rule 403 allows these kinds of attacks. 
(2) the impeaching evidence is likely to expose false testimony initially elicited during direct examination of the witness being impeached, or volunteered by the witness on crossexamination; and ${ }^{234}$

(3) the interests of justice require its admission. ${ }^{235}$

The format of the proposed rule is suggested by Florida's version of Federal Rule $607 .{ }^{236}$ Both rules state who may impeach a witness and then list the modes of impeachment as subsections. The subsections of section (a) of the proposed rule plainly provide that extrinsic evidence may be admitted to prove bias, lack of opportunity or capacity to observe, recollect or communicate, and conviction of a crime. These are noncollateral matters under the traditional rule because the evidence does more than simply raise a contradiction between testimonies.

The proposed rule permits the extrinsic impeachment of testimony concerning linchpin facts. If a court views a linchpin fact as collateral because it does not meet Wigmore's strict test, and the witness to be impeached did not raise the fact, the impeachment still may be perinitted under proposed rule 607(a)(6). This catch-all provision is designed to permit trial courts to use their discretion to escape the rigors of the collateral-matter rule.

Subsection (b) delineates the sweeping-claims exception to the collateral-matter rule. The proposal provides that a party who seeks to introduce extrimsic evidence to contradict a witness on an "immaterial"237 point must surmount three obstacles. First, the proponent of the evidence must convince the court that the value of the rebuttal is greater than the dangers of prejudice, time wasting, and jury confusion. If no further prerequisites were imposed, evidence offered under the

234. Compare this formulation with Professor Black's proposed Texas rule 607(b), note 219 supra.

235. Professor Black suggested this language.

236. See note 218 supra.

237. The word "collateral" has been avoided purposefully. It has been justly criticized. "The value adjective 'collateral' hides more than it reveals." $2 \mathrm{D}$. Louisell \& C. MuELLER, supra note $71, \S 129$, at 49 . "[It] tends both to conceal the analytical process, and to hide the reality of the discretionary factor." Id. at 67. Except for the title to subsection four of rule 1004, the Federal Rules of Evidence do not use the words "collateral" or "noncollateral." Thus, it was thought wise not to introduce the term here. The Federal Rules of Evidence have abandoned the term "material" as "loosely used and ambiguous." See Advisory Committee's note to FED. R. Evid. 401. In its place, the rules use the words "of consequence to the determination of the action." FED. $R$. EviD. 401. Even if this phrase is an improvement, it is not used in the proposed revisions of rule 607 because it makes the language cumbersome. And so long as the reader knows that "material" means "of consequence to the determination of the action," there is no good reason, aside from a slavish desire for consistency, to jettison a word that has been part of the definition of the collateral-matter rule for generations. 
exception would always be admissible under subsection (a)(6) of the proposed rule regardless of when and how the matter was raised at trial. However, when the mode of impeachment is by contradiction on a collateral point with other testimony, subsection (b)(2) requires that the matter be first raised on direct examination or volunteered on crossexamination. In effect, the witness must invite impeachment by his own testimony, and in such a manner as to violate our basic notions of fair play. The judge must be convinced that the testimony to be impeached is a knowing fabrication and that the rebuttal evidence is likely to expose it. Subsection (b)(3) may seem redundant, but it captures the essence of the sweeping-claims exception-to ensure the integrity of a trial's truth-seeking function. ${ }^{238}$

\section{B. A Proposed Amendment to Federal Rule of Evidence 608.}

The cases show that courts tend to read rule 608 (b) too broadly. ${ }^{239}$ Often they view it as prohibiting all impeachment with extrinsic evidence of specific misconduct not resulting in a conviction. ${ }^{240}$ Of course, this view conflicts with the collateral-impeachment rule, which allows impeachment with evidence of misconduct that demonstrates bias, lack of perception, and so forth. Redrafting rule 608 as suggested should solve this continuing problem by clarifying the narrow area of the rule's application. The reworded 608(b) emphasizes that extrinsic evidence of specific mstances of conduct is prohibited only when the conduct is offered as circumstantial evidence of a witness's character for truthfulness or untruthfulness, i.e., to show that the witness generally is an untrustworthy person who should not be believed. ${ }^{241}$

238. See, e.g., United States v. Salvitti, 451 F. Supp. 195 (E.D. Pa.), affd, 588 F.2d 824 (3d Cir. 1978). In Salvitti the defendant, a city official charged with taking a bribe, testified he had never received any money in envelopes and presented a large nuinber of character witnesses. The court permitted the prosecutor to rebut this testimony with evidence of an uncharged bribe, stating, "[defendant] plainly sought to convey to the jury ... that [he] was an honorable public servant who had never received a bribe," 451 F. Supp. at 203, and that in this setting it would have been "decidedly unfair" to the Government to exclude the rebuttal testimony. Id. at 205. In United States v. Batts (Batts II), 573 F.2d 599, 603 (9th Cir.), cert. denied, 439 U.S. 859 (1978), the court, affirming a conviction, noted, "[b]y admitting the rebuttal evidence, the trial court inerely permitted completion of the [previously mispainted] picture as to appellant's true involveinent and knowledge in the drug world and thereby corrected a distorted view of appellant's testimony and his attempts to portray naivety."

239. See notes $135-48$ supra and accompanying text.

240. Cf. United States v. Leake, 642 F.2d 715, 718-19 (4th Cir. 1981) (trial court erroneously read rule 608(b) as prohibiting cross-examination concerning the witness's prior fraudulent conduct not resulting in a conviction).

241. See C. MCCORMICK, supra note 2 , $\$ 47$, at 15 n.57 (Supp. 1978). Rule 404(b) also prohibits the other impermissible use of prior-bad-acts evidence: to prove that the actor has a propensity to act in a certain manner and, thus, as alleged, that lie probably acted again in that way. 
Redrafting rule 608(b) also affords an opportunity to correct the illogical sequence of its two sentences. Normally, the witness benig impeached is cross-examined before the opponent attempts to introduce extrinsic impeaching evidence. Therefore, the rule should first address cross-examination of the witness being attacked. The following proposed rule 608(b) fulfills both of these purposes:

Rule 608

Evidence of the Character of a Witness ${ }^{242}$

(a) Opinion and reputation evidence of character. . . .

(b) Specific instances of conduct. In the discretion of the court, specific instances of conduct, if probative of truthfulness or untruthfulness, may be inquired into on cross-examination of a witness

(1) concerning his character for truthfulness or untruthfulness or

(2) concerning the character for truthfulness or untruthfulness of another witness about whose character the witness being cross-examined has testified. Except for conviction of a crime as provided in Rule 609, specific instances of conduct offered as circumstantial evidence of a witness's character for truthfulness or untruthfulness may not be proved by extrinsic evidence.

\section{CONCLUSION}

When rules 607 and $608(\mathrm{~b})$ as proposed here are read together, they eliminate the danger that a trial court will exclude contradicting evidence that also demonstrates the impeached witness's bias or other noncollateral inatters that the rule would prohibit. However, a party's contradiction of a witness's testimony on a collateral point merely for the sake of contradiction is not permitted unless the conditions of rule 607(b) are fulfilled.

The Federal Rules of Evidence are not intended to cover every aspect of the law of evidence. The gaps permit the courts to expand and improve the rules. However, this article has demonstrated that the failure of the rules to address collateral contradiction and its exceptions and the ambiguity of rule 608(b) have created enough confusion in the courts to warrant the reinedies recommended.

242. Arguably, this section's current title, "Evidence of Character and Conduct of Witness," is misleading. It appears to draw a conceptual distinction between the character of witnesses on one hand, and the conduct of witnesses on the other. But rule 608 intends no such dichotony. Specific-conduct evidence can be merely a form of character evidence, as is reputation and opinion testimony. The rule simply prohibits extrinsic evidence of specific instances of a witness's conduct when offered as proof of character for truthfulness or untruthfulness. See FED. R. Evid. 608, Advisory Committee Notes. 